\title{
Analysis of Rainfall through Space - Time during 1999-2014 in Salem District, South India
}

\author{
P.Arulbalaji, B.Gurugnanam
}

Centre for Applied Geology, Gandhigram Rural Institute - Deemed University, Dindigul, Tamil Nadu, India

\begin{abstract}
The present study deals about the Rainfall assessment using various recent techniques with the help of remote sensing and GIS in Salem District, South India. The rainfall assessment carried over a period of 16 years from 1999 to 2014, which are clearly analyzed by using mean annual rainfall, mean seasonal rainfall, mean annual rainfall variability, mean seasonal rainfall variability, mean annual precipitation ratio and mean seasonal precipitation ratio methods. The methodology adopted based on literature study and which has given an accurate results. Therefore, the output shows that the study area has received $1 \%, 19 \%, 41 \%$ and $39 \%$ of precipitation in winter, summer, southwest and northeast season respectively and the average annual rainfall is relatively more in $N$ and $N E$ and it is gradually decreases the eastern, western and southern parts of the study area. The rainfall variability indicates more than $100 \%$ in winter season except Nangavalli which is indicate the not dependable rainfall and other three season's rainfall variability less than 100\% except Veeraganoor station, which is indicate the dependable rainfall available during these period. The precipitation ratio is less abnormality during $S W$ and $N E$ season and high abnormality during summer and winter season. Finally, rainfall variation assessment depicts that the rainfall conditions in Salem district is normal and fluctuation depends upon time and space.
\end{abstract}

Keywords - Variability, Precipitation Ratio, time, Space.

\section{INTRODUCTION}

Agricultural activities are the one of the main aspects of a country economic growth. . Rainfall is a main source of Agriculture productions. So, Rainfall play a vital role for Socio-Economic growth of an area, region and Country. Generally rainfall has a fluctuating character in year-toyear. Rainfall is a dynamic input for hydrologic studies and it is serious for obtaining accurate results (Suk etal. 2011). Monsoon rainfall has been playing a vital role in the nature and economy of Indian continent (Zaheer etal.2015). Forecasting and monitoring of precipitations are very important for management of future droughts or floods
(Wei- Chiang Hong and Ping-Feng Pai 2007, RicoRamirezetal. 2015). The amount of rainfall is varied from either in space or in time (Mahalingam etal. 2014). Rainfall is exclusive variable, which reflects numerous factors regionally and globally (Jegankumar etal. 2012). Therefore, this study will assist the people to predict meteorological condition variation in spatial and temporally of Salem district. Water resource management is understanding by to know about the local precipitation patterns and which can vary in space and time considered on factors from different spatial scales such as macroscopic atmospheric circulation and topographical changes(Hwa-lung et.al.2015,). Rainfall variation and the detection of rainfall extremes is a function of scale, so high space and time resolution data are ideal to identify extreme events and exact prediction of future variability (Williamset al. 2010, Renji Remesan and Holman, 2015). Rainfall is a main triggering factor for natural hazards like landslide and flood, 90\% involved and which are closely connected to the strong rainfall (Hengxine et.al. 2003, Theodosisos Kritikos and Tim davies 2014, Bai Shi-biao etal. 2013, Sang-Soo Jeon 2014). Climatology is one of the main factor, which is directly or indirectly influences by hydrology predictions (Azadeh ahmadi et al. 2014, Mari R.Tye and Daniel Cooley. 2015). Representation of precipitation changes in based on elevation in an area indicated that the possibilities of orographic precipitation found in the hilly regions (Zekai sen and Zeyat habib 2000). Remote sensing and Geographical Information System has been used to create model in identification of rainfall-based assessment (Okan fistikoglu and Nilgun B. Harmancioglu 2002).India receives more rainfall during $\mathrm{SW}$ monsoon than the other seasons(Thilagavathi et al.2014, Priyadharshini and Arucham 2015, Tharanitharan Venkatesan and Srinivasan Krishnamoorthy, 2014). Built-up catchments are naturally characterized by high spatial variability and quick runoff which are in short response times (Susana ochoa-rodriquez etal.2015). Gurugnanam etal. (2012) have analyzed that, the average rainfall of Salem district received less than $200 \mathrm{~mm}$ during 1998-2007, which was very less than actual rainfall. 


\section{MATERIALS AND METHODS}

The daily rainfall data collected from the year 1999 to 2014. The daily rainfall data calculated into monthly, then the monthly data divided into season and monsoon wise data. Totally there are 17 rain gauge stations in the study area, which are Veeraganoor, Yercaud, Thammampatti, Valapadi, Omalur, Pillukurichi, Salem City, Athur, Gangavalli, Salem Junction, Edapadi, Kolathur, Anaimaduvu Reservoir, Kullampatti, Mettur, Nangavalli and Sankagiri. The 17 rain gauge stations are given Fig.3. Finally, rainfall data analyzed for mean annual and mean seasonal rainfall, mean annual and mean seasonal rainfall variability, mean annual and mean seasonal precipitation ratio of 16 years interval of 1999-2014. The flow chart methodology of rainfall assessment is given in Fig.1. Finally, the spatial distribution maps prepared from the attributed rainfall data.

\section{Study Area}

The present study is carried out in Salem District (Fig.-2), which is located in-between latitude $11^{\circ} 39^{\prime} 52^{\prime \prime}$ and Longitude $78^{\circ} 8^{\prime} 45^{\prime \prime}$ and the total area covered by 5232 $\mathrm{Km}^{2}$. The average Mean Sea Level is $278 \mathrm{~m}$. The study area situated at north side of Nagaramalai hill, West side of Kanjamalai hill, East side of Godumalai hill, , South side of Jarugumalai hill, North East side of Shervaroy hills and South West side of Kariyaperumal Hills.

\section{Mean Annual Rainfall}

Since from 1999 to 2014 the study area receivesmean annual rainfall of $816 \mathrm{~mm}$, and it ranges from $329 \mathrm{~mm}$ (Veeraganoor) to $1492 \mathrm{~mm}$ (Yercaud). The mean annual rainfall data is given in Table 1. The rain gauge stations Yercaud, Thammampatti, Valapadi, Omalur, Salem, Athur, Mettur, Kullampatti, and Nangavalli receives high rainfall than average rainfall, and Anaimaduvu station receives nearly equal rainfall than average rainfall. The rest of the stations receives low rainfall than average rainfall. The mean annual rainfall spatial distribution map computed by inverse distance weighted (IDW) method using Arc GIS 10.2 software. The spatial distribution map of mean annual rainfall is given in Fig.4. The map clearly represent that, the mean annual rainfall variation between one stations to other stations. According to the rainfall data, the spatial distributions divided into five classes with $250 \mathrm{~mm}$ interval, which are very low (<500 mm), low (500-750 mm), moderate $(750-1000 \mathrm{~mm})$, high $(1000-1250 \mathrm{~mm})$, very high $(>1250 \mathrm{~mm})$. Yercaud station only receives a very high $(>1250 \mathrm{~mm})$ rainfall in the area of $109 \mathrm{~km}^{2}$. Mettur and adjacent part of Yercaud hill receives high (1000-1250 mm) rainfall in the area of $579 \mathrm{~km}^{2}$. The very high and high rainfall levels occurs in the high altitude areas only.Most part of the study area falls under the moderate (750-1000 $\mathrm{mm}$ ) level rainfall including Nangavalli, Omalur, Kullampatti, Salem City, Valapadi, Anaimadu Reservoir, Athur and Thammampatti in the area of $3664 \mathrm{~km}^{2}$. Low (500-750 mm) level rainfall locates in Gangavalli, Salem Junction, Pillukuruchi, Sankagiri, Edapadi and Kolathur. These locations situate in eastern and western part of the study area. Low level rainfall cover an area of $710 \mathrm{~km}^{2}$. Very low $\left(<500 \mathrm{~mm}\right.$ ) level rainfall cover an area of $168 \mathrm{~km}^{2}$ and it is mainly found in Veeraganoor and its adjacent parts. The moderate to very low rainfall areas are low altitudes and plain regions.

\section{Seasonal Rainfall}

\section{Winter Season}

The winter season rainfall contributes very less $(1 \%)$ than other seasons and it ranges from $1 \mathrm{~mm}$ to $12 \mathrm{~mm}$ (Table 1). The highest rainfall in winter season occurs in the Yercaud station, which is high altitude region and the remaining areas receives less than $10 \mathrm{~mm}$ rainfall. The average winter season rainfall is $5 \mathrm{~mm}$. Yercaud, Thammampatti, Pillukurichi, Edapadi, Kullampatti, and Mettur stations receives high rainfall than average rainfall and the rest of the stations receives low rainfall than average rainfall.The spatial distribution map of the winter season is given in Fig. 5. The spatial distribution of winter season rainfall divided in to five classes with $2.5 \mathrm{~mm}$ interval, which are very low $(<2.5 \mathrm{~mm})$, low $(2.5-5 \mathrm{~mm})$, moderate $(5-7.5 \mathrm{~mm})$, high $(7.5-10 \mathrm{~mm})$ and very high $(>10 \mathrm{~mm})$. The very low $(<2.5$ $\mathrm{mm}$ ) level rainfall occurs in Nangavalli, Salem Junction and Veeraganoor stations in the area of $323 \mathrm{~km}^{2}$. Low $(2.5-5$ $\mathrm{mm}$ ) level rainfall covers an area of $3711 \mathrm{~km}^{2}$ and the locations are Kolathur, Mettur, Omalur, Salem city, Sankagiri, Valapadi, Anaimaduvu Resrvoir, Attur and Gangavalli stations. Moderate $(5-7.5 \mathrm{~mm})$ level rainfall covers an area of $905 \mathrm{~km}^{2}$ and the locations are adjacent area of Yercaud, Edapadi and Kullampatti. High (7.5-10 $\mathrm{mm}$ ) rainfall locates in Pillukurichi and some part of Yercaud, in the area of $269 \mathrm{~km}^{2}$. The very high $(>10 \mathrm{~mm})$ rainfall region is Yercaud station and it covers $24 \mathrm{~km}^{2}$.

\section{Summer Season}

The summer season contributes $19 \%$ of rainfall, it is higher than winter season rainfall. During the summer season, the rainfall ranges from $47 \mathrm{~mm}$ (Veeraganur) to $264 \mathrm{~mm}$ (Yercaud) with average rainfall of $156.5 \mathrm{~mm}$ (Table 1). The spatial distribution map of the summer season is given in Fig. 6. Yercaud, Omalur, Salem city, Salem junction, Edapadi, Kolathur, Anaimaduvu, Mettur, Kullampatti, and Nangavalli receives high rainfall than average rainfall, and Sankagiri station receives nearly equal rainfall than average 
rainfall and rest of the stations receives low rainfall than average rainfall.The spatial distribution of summer season rainfall divided into five classes with $55 \mathrm{~mm}$ interval,which are very low $(<55 \mathrm{~mm})$, low $(55-110 \mathrm{~mm})$, moderate $(110$ $165 \mathrm{~mm})$, high $(165-220 \mathrm{~mm})$ and very high $(>220$ $\mathrm{mm})$. The very low level rainfall $(<55 \mathrm{~mm})$ station is Veraganoor and its cover an area of $30 \mathrm{~km}^{2}$. Low level rainfall $(55-110 \mathrm{~mm})$ occurs in Gangavalli and adjacent parts of veraganoor stations in the area of $497 \mathrm{~km}^{2}$. Moderate level rainfall (110-165 $\mathrm{mm})$ occurs in Pillukurichi, Edapadi, Sankagiri, Salem Junction, Anaimaduvu, Valapadi, Athur and Thammampatti stations in the area of $1968 \mathrm{~km}^{2}$. High level rainfall $(165-220 \mathrm{~mm})$ occur in Kullampatti, Kolathur, Mettur, Nangavalli, Omalur and Salem city in the area of $2604 \mathrm{~km}^{2}$. Very high level rainfall $(>220 \mathrm{~mm})$ occur in Yeacaud station in the area of $129 \mathrm{~km}^{2}$.

\section{Southwest Monsoon}

The southwest monsoon contributes $41 \%$ of rainfall, it is higher than summer season. During the southwest monsoon, rainfall ranges from $92 \mathrm{~mm}$ (Veeraganur) to $718 \mathrm{~mm}$ (Yercaud) with the average rainfall of $332.4 \mathrm{~mm}$ (Table 1). The spatial distribution map of the southwest monsoon is given in Fig. 7. Yercaud, Valapadi, Omalur, Salem, Athur, Anaimaduvu, Mettur, and Nangavalli stations receives high rainfall than average rainfall, and the rest of the stations receives low rainfall than average rainfall.The spatial distribution of southwest monsoon divided into five classes with $150 \mathrm{~mm}$ interval, which are very low (<150 mm), low (150-300 $\mathrm{mm})$, moderate $(300-450 \mathrm{~mm})$, high (450-600 $\mathrm{mm})$ and very high $(>600 \mathrm{~mm})$. The very low $(<150 \mathrm{~mm})$ level rainfall occurs in Gangavalli and Veeraganoor stations in the area of $134 \mathrm{~km}^{2}$. Low $(150-300 \mathrm{~mm})$ level rainfall covers an area of $1089 \mathrm{~km}^{2}$ and the locations are Kolathur, Pillukurichi, Sankagiri, Thammampatti and adjacent parts of Gangavalli station. Moderate (300-450 mm) level rainfall covers an area of $3299 \mathrm{~km}^{2}$ and the locations are Mettur, Nangavalli, Kullampatti, Edapadi, Salem Junction, Anaimaduvu reservoir, Valapadi and Athur. High (450-600 $\mathrm{mm}$ ) level rainfall locates in Omalur, Salem city and adjacent part of Yearcaud in the area of $615 \mathrm{~km}^{2}$. The very high (>600) level rainfall region is Yercaud station and it covers an area of $93 \mathrm{~km}^{2}$.

\section{Northeast Monsoon}

The northeastmonsoon contributes $39 \%$ of rainfall which is higher than winter and summer season. During the northeast monsoon, rainfall ranges varies $190 \mathrm{~mm}$ (Veeraganur) to $496 \mathrm{~mm}$ (Yercaud) with the average rainfall of $322.5 \mathrm{~mm}$ (Table 1). The spatial distribution map of the northeastmonsoon is given in Fig.8. Yercaud, Thammampatti, Valapadi, Salem, Athur, Mettur, Kullampatti, and Nangavalli receives high rainfall than average rainfall, and the rest of the stations receives low rainfall than average rainfall.The spatial distribution of northeast monsoon rainfall divided into five classes with 80 mm interval,which are very low $(<240 \mathrm{~mm})$, low $(240-320$ $\mathrm{mm})$, moderate $(320-400 \mathrm{~mm})$, high $(400-480 \mathrm{~mm})$ and very high $(>480 \mathrm{~mm})$. The very low $(<240 \mathrm{~mm})$ level rainfall occurs in Veeraganoor station with the area of 130 $\mathrm{km} 2$. Low (240-320 mm) level rainfall covers an area of $2141 \mathrm{~km} 2$ and the locations are Kolathur, Pillukurichi, Edapadi, Sankagiri, Omalur, Salem Junction, Anaimaduvu reservoir and Gangavalli stations. Moderate (320-400 mm) level rainfall covers an area of $2663 \mathrm{~km} 2$ and the locations are Mettur, Nangavalli, Kullampatti, Salem city, Valapadi and Athur. High (400-480 mm) level rainfall occurs in Thammampatti and adjacent part of Yearcaud in the area of $280 \mathrm{~km} 2$. The very high $(>480 \mathrm{~mm})$ level rainfall region is Yercaud station in the area of $15 \mathrm{~km} 2$.

\section{Rainfall Variability}

Rainfall variability defined as the deviation from mean or ratio of the standard deviation to the mean rainfall and in other words variability of co-efficient of variation (Rathod, 2010). The rainfall variability calculated using the coefficient of variations of selected 16 years data. The coefficient of variation (CV) defined as the standard deviation divided by the mean value. The results of rainfall variability is given in Table 4.8. Jegankumar etal.2012; Priyadharshini and Aruchamy, 2015 have emphasized that the higher value is the variability percentage, the lower value is the dependability and vice versa. For the monthly case less than $100 \%$ of co-efficient of variation is dependable, while more than $100 \%$ of co-efficient of variation is not dependable rainfall.

\section{$\mathrm{CV}=(\mathrm{SD} / \mathrm{Mean}) \times 100 \quad$ Where $S D=$ Standard deviation}

\section{Mean Annual Variability}

The mean annual rainfall variability is $43 \%$ and it's range from $19 \%$ to $119 \%$ (Table 2). The minimum variability occurs in Yercaud and Thammampatti and the maximum variability occurs in Veeraganoor.The stations Veeraganoor, Gangavalli, Salem junction, Kolathur and mettur have high rainfall variability than average rainfall variability and the other stations have low rainfall variability than average rainfall variability. The spatial distribution map of the mean annual rainfall variability is given in Fig.9. The spatial distribution of rainfall variability divided into five classes 
with $25 \%$ interval,which are very low $(<25 \%)$, low $(25-50$ $\%)$, moderate $(50-75 \%)$, high $(75-100 \%)$, very high $(>100$ $\%)$. The very low $(<25 \%)$ rainfall variability occurs in Yercaud, Salem city, Omalur and Thammampatti stations in an area of $232 \mathrm{~km} 2$. Low $(25-50 \%)$ rainfall variability covers an area of $3987 \mathrm{~km} 2$ and occurs in Pillukurichi, Edapadi, Kullampatti, Nangavalli, Vallapadi, Sankagiri, Anaimaduvu reservoir and Athur station. Moderate (50-75 $\%$ ) rainfall variability covers an area of $709 \mathrm{~km} 2$ and occurs in Kolathur, Mettur, Salem junction and adjacent parts of Gangavalli. High (75-100\%) rainfall variability locates in Gangavalli in the area of $221 \mathrm{~km} 2$. The very high (>100\%) rainfall variability region is Veeraganoor station in the area of $80 \mathrm{~km} 2$.

\section{Winter Season Variability}

The average rainfall variability of winter season is $208 \%$ and it's range from $0 \%$ to $374 \%$ (Table 2). The stations Veeraganoor, Omalur, Salem junction, Kullampatti and Sankagri have high rainfall variability than average rainfall variability and the other stations have low rainfall variability than average rainfall variability. The spatial distribution map of the winter season rainfall variability is given in Fig.10. The spatial distribution of rainfall variability divided into five classes with $75 \%$ intervals, which are very low $(<75 \%)$, low (75-150\%), moderate (150-225\%), high (225-300\%), very high $(>300$ $\%)$. The Very low $(<75 \%)$ rainfall variability occurs in Nangavalli station and it covers an area of $60 \mathrm{~km} 2$.

Low $(75-150 \%)$ rainfall variability covers an area of 355 $\mathrm{km}^{2}$ and occurs in Vallapadi, Anaimaduvu reservoir and adjacent part of Nangavalli station. Moderate (150-225\%) rainfall variability covers an area of $3467 \mathrm{~km}^{2}$ and occurs in Kolathur, Mettur, Pillukurichi, Yercaud, Salem city, Athur, Thammampatti and Gangavalli. High (225-300 \%) rainfall variability locates in Edapadi, Kullampatti and covers an area of $1127 \mathrm{~km}^{2}$. The very high (>300 \%) rainfall variability regions are Omalur, Salem junction, Veeraganoor, Sankagiri stations and its cover an area of 220 $\mathrm{km}^{2}$.

\section{Summer Season Variability}

The average rainfall variability of summer season is $70 \%$ and it's range from $45 \%$ to $174 \%$ (Table 2). The stations Veeraganoor, Valapadi, Gangavalli, Kolathur have high rainfall variability than average rainfall variability and rest of the stations have low rainfall variability than average rainfall variability. The spatial distribution map of the summer season rainfall variability is given in Fig.11. The spatial distribution of rainfall variability divided into five classes with $60 \%$ intervals, which are very low $(<60 \%)$, low (60-90\%), moderate (90-120\%), high (120-150\%), very high $(>150 \%)$.

The very low $(<60 \%)$ rainfall variability occurs in Yercaud, Omalur, Salem city, Pillukurichi, Edapadi, Kullampatti, Sankagiri, Anaimaduvu reservoir, Athur and Thammampatti stations and covers an area of $2217 \mathrm{~km} 2$. Low (60-90 \%) rainfall variability covers an area of $2464 \mathrm{~km} 2$ and the locations are Mettur, Nangavalli, Valapadi and adjacent parts of Kolathur station. Moderate (90-120 \%) rainfall variability covers an area of $343 \mathrm{~km} 2$ and the location is Gangavalli. High (120-150 \%) rainfall variability locates in adjacent parts of Veeraganoor station in the area of 138 $\mathrm{km} 2$. The very high $(>150 \%)$ rainfall variability region is Veeraganoor station and it covers an area of $67 \mathrm{~km} 2$.

\section{Southwest Monsoon Variability}

The average rainfall variability of southwest monsoon is 45 $\%$ and it's range from $22 \%$ to $128 \%$ (Table 2). The stations Veeraganoor, Gangavalli, Salem junction, Kolathur and Kullampatti have high rainfall variability than average rainfall variability and the other stations have low rainfall variability than average rainfall variability. The spatial distribution of the southwest monsoon rainfall variability is given in Fig.12. The rainfall variability divided into five classes with $25 \%$ intervals, and the classes are very low $(<25 \%)$, low $(25-50 \%)$, moderate $(50-75 \%)$, high $(75-100$ $\%)$, very high $(>100 \%)$.

The very low $(<25 \%)$ rainfall variability occurs in Yercaud, Anaimaduvu reservoir and Valapadi Stations in an area of $126 \mathrm{~km} 2$. Low (25-50\%) rainfall variability covers an area of $4282 \mathrm{~km} 2$ and occurs in Mettur, Nangavalli, Omalur, Pillukurichi, Edapadi, Kullampatti, Sankagiri and Athur stations. Moderate (50-75\%) rainfall variability covers an area of $462 \mathrm{~km} 2$ and occur in Kolathur, Salem junction and adjacent parts of Gangavalli station. High (75-100 \%) rainfall variability locates in Gangavalli station and covers an area of $237 \mathrm{~km} 2$. The very high (>100 \%) rainfall variability region is Veeraganoor station and it covers an area of $123 \mathrm{~km} 2$.

\section{Northeast Monsoon Variability}

The average rainfall variability of northeast monsoon is 59 $\%$ and it's range from $32 \%$ to $120 \%$ (Table 2). The stations Veeraganoor, Gangavalli, Salem junction, Kolathur and Nangavalli have high rainfall variability than average rainfall variability and the other stations have low rainfall variability than average rainfall variability. The spatial distribution map of the northeast monsoon rainfall variability is given in Fig.13. The spatial distribution of rainfall variability divided into five classes with $20 \%$ intervals and the classes are very low (<40\%), low (40-60 
$\%)$, moderate (60-80\%), high (80-100\%), very high (>100 $\%)$.

The very low $(<40 \%)$ rainfall variability occurs in Yercaud, Omalur, Salem city and Thammampatti stations in the area of $188 \mathrm{~km} 2$. Low (40-60\%) rainfall variability covers an area of $3705 \mathrm{~km} 2$ and occurs in Pillukurichi, Edapadi, Kullampatti, Sankagiri, Valapadi, Anaimaduvu reservoir and Athur stations. Moderate (60-80\%) rainfall variability covers an area of $936 \mathrm{~km} 2$ and occurs in Kolathur, Mettur, Nangavalli, Salem junction and adjacent parts of Gangavalli station. High (80-100\%) rainfall variability locates in Gangavalli station in the area of $269 \mathrm{~km} 2$. The very high $(>100 \%)$ rainfall variability region is Veeraganoor station and its cover an area of $130 \mathrm{~km} 2$.

\section{Precipitation Ratio (PR)}

The precipitation ratio or abnormalities of rainfall has been calculated using a simple ratio of precipitation. Precipitation ratio is the difference between maximum and minimum rainfall of over the study period of mean value. The precipitation ratio may give the stability of rainfall with spatial pattern. Higher value of PR is the high abnormality in rainfall and the lower PR value is the less abnormality in rainfall. The $\mathrm{PR}$ formula is given below.

Precipitation Ratio $=(\mathrm{Px}-\mathrm{Pn}) / \mathrm{Pm} \times 100$

Where; Px = Maximum of Rainfall

Pn = Minimum of Rainfall

$\mathrm{Pm}=$ Mean Rainfall

The result of precipitation ratio analysis are given in Table 3.

\section{Mean Annual Precipitation Ratio}

The mean annual precipitation ratio of the study area is 132 $\%$ with maximum abnormality in Veeraganoor (301\%) and minimum abnormality in Omalur (53\%) (Table 3). The spatial distribution map of the mean annual precipitation ratio is given in Fig. 14. The spatial distribution of precipitation ratio divided into five classes with $50 \%$ interval, which are very low $(<100 \%)$, low (100-150\%), moderate (150-200\%), high (200-250\%) and very high $(>250 \%)$.

The very low (<100\%) PR occurs in Yercaud, Omalur, Salem city, Sankagiri and Thammampatti Stations in the area of $1150 \mathrm{~km} 2$. Low (100-150 \%) PR covers an area of $3143 \mathrm{~km} 2$ and the stations are Pillukurichi, Mettur, Nangavalli, Edapadi, Valapadi, Anaimaduvu reservoir and Athur stations. Moderate (150-200 \%) PR covers an area of $626 \mathrm{~km} 2$ and the stations are Kolathur, Kullampatti, Salem junction and surrounding parts of Gangavalli station. High (200-250 \%) PR locates in Gangavalli station with 205 $\mathrm{km} 2$. The very high $(>250 \%) \mathrm{PR}$ region is Veeraganoor station and its cover an area of $104 \mathrm{~km} 2$.

\section{Winter Season Precipitation Ratio}

The average winter season precipitation ratio of the study area is $748 \%$, and it ranges from $0 \%$ to $1437.5 \%$ (Table 3). The spatial distribution map of the winter season precipitation ratio is given in Fig. 15. The spatial distribution of winter season precipitation ratio divided into five classes with $300 \%$ intervals and the intervals are very low $(<300 \%)$, low (300-600\%), moderate $(600-900 \%)$, high $(900-1200 \%)$ and very high $(>1200 \%)$. The very low $(<300 \%)$ PR occurs in Nangavalli and Salem city stations in the area of $67 \mathrm{~km} 2$. Low (300-600 \%) PR covers an area of $1563 \mathrm{~km} 2$ and occurs in Kolathur, Mettur, Valapadi, Anaimaduvu reservoir and Athur stations. Moderate (600$900 \%)$ PR covers an area of $2666 \mathrm{~km} 2$ and occurs in Pillukurichi, Edapadi, Kullampatti, Yercaud and Gangavalli stations. High (900-1200 \%) PR locates in adjacent parts of Omalur, Salem junction, Sankagiri and Veeraganoor stations in the area of765 km2. The very high (>1200\%) PR stations are Veeraganoor, Omalur, Salem junction, Sankagri and it covers an area of $170 \mathrm{~km} 2$.

\section{Summer Season Precipitation Ratio}

The summer season precipitation ratio of the study area is $210 \%$, and it ranges from $70 \%$ to $486 \%$ (Table 3). The spatial distribution map of the summer season precipitation ratio is given in Fig.16. The spatial distribution of summer season precipitation ratio divided into five classes with $100 \%$ intervals and the intervals are very low $(<100 \%)$, low (100-200 \%), moderate (200-300\%), high (300-400\%) and very high $(>400 \%)$. The very low $(<100 \%)$ PR occurs in Sankagiri in the area of $48 \mathrm{~km} 2$. Low (100-200 \%) PR covers an area of $1864 \mathrm{~km} 2$ and occurs in Kolathur, Kullampatti, Yercaud, Anaimaduvu reservoir and Thammampatti stations. Moderate (200-300 \%) PR covers an area of $3075 \mathrm{~km} 2$ and occurs in Mettur, Nangavalli, Omalur, Pillukurichi, Edapadi, Salem Junction, Salem city, Valapadi, Athur and Gangavalli stations. High (300-400 \%) PR locates in adjacent parts of Veeraganoor stations which covers an area of $158 \mathrm{~km} 2$. The very high (>400\%) PR region is Veeraganoor station and it covers an area of 85 $\mathrm{km} 2$.

\section{Southwest Monsoon Precipitation Ratio}

The average southwest monsoon precipitation ratio of the study area is $138 \%$, and it ranges from $62 \%$ to $330 \%$ (Table 3). The spatial distribution map of the southwest monsoon precipitation ratio is given in Fig. 17. The spatial distribution of southwest monsoon precipitation ratio divided into five classes with $80 \%$ intervals and the 
intervals are very low $(<80 \%)$, low $(80-160 \%)$, moderate (160-240\%), high (240-320\%) and very high (>320\%). The very low $(<80 \%)$ PR occurs in Valapadi and Yercaud, in the area of $110 \mathrm{~km} 2$. Low (80-160\%) PR covers an area of $4285 \mathrm{~km} 2$ and the stations are Mettur, Nangavalli, Omalur, Pillukurichi, Edapadi, Anaimaduvu reservoir, Athur and Thammampatti. Moderate (160-240 \%) PR covers an area of $634 \mathrm{~km} 2$ and the stations are Kolathur, Kullampatti, Sangagiri, Salem junction and Gangavalli. High (240-320 \%) PR locates in adjacent parts of Veeraganoor station in the area of $185 \mathrm{~km} 2$. The very high (>320\%) PR region is Veeraganoor station and it covers an area of $15 \mathrm{~km} 2$.

\section{Northeast Monsoon Precipitation Ratio}

The average northeast monsoon precipitation ratio of the study area is $189 \%$, and it ranges from $48 \%$ to $278 \%$ (Table $3)$.The spatial distribution map of the northeast monsoon precipitation ratio is given in Fig.18. The spatial distribution of northeast monsoon precipitation ratio divided into five classes with $60 \%$ intervals and the intervals are very low $(<60 \%)$, low (60-120\%), moderate (120-180\%), high $(180-240 \%)$ and very high $(>240 \%)$. The very low $(<60$ $\%)$ PR occur in Salem city in the area of $7 \mathrm{~km}^{2}$. Low (60$120 \%) P R$ cover an area of $131 \mathrm{~km}^{2}$ and the stations are Omalur, Thammampatti and adjacent parts of Salem city. Moderate (120-180 \%) PR covers an area of $2515 \mathrm{~km}^{2}$ and the stations are Yercaud, Valapadi, Athur and Sankagiri. High (180-240 \%) PR locates in Kolathur, Mettur, Nangavalli, Pillukurichi, Edapadi, Kullampatti and Anaimaduvu reservoir stations in the area of $2281 \mathrm{~km}^{2}$. The very high (>240\%) PR regions are Veeraganoor and Gangavalli stations and it covers an area of $296 \mathrm{Km}^{2}$.

\section{CONCLUSION}

The analysis of the rainfall data has shown that the average rainfall ranges from $329 \mathrm{~mm}$ to $1492 \mathrm{~mm}$. it is clearly evidenced that the high altitude area likely yercaud stations has received more rainfall than plain regions. In general, the rainfall is found to be relatively higher in the hilly regions and lower in the plain regions. The average annual rainfall is relatively more in $\mathrm{N}$ and $\mathrm{NE}$ and it is gradually decreasing in Eastern, Western and Southern parts. It is found that the southwest monsoon is considerably more active in northern, northeastern and northwestern part than other direction, whereas the northeast monsoon is more active in north and northeastern part. The relative percent of rainfall during summer relatively more on northern, northeastern and eastern part, whereas winter seasons are relatively more on northern and eastern part.The Southwest season has contributed more than the other season of rainfall. The rainfall variability indicates more than $100 \%$ in winter season except Nangavalli, which is indicating the not dependable rainfall and other three season's rainfall variability less than $100 \%$ except Veeraganoor station, which is indicating the dependable rainfall available during these period. The precipitation ratio is less abnormality during SW and NE season and high abnormality during summer and winter season. Based on mean annual precipitation ratio eastern part of the study area having high abnormality, Central and western part of the study area have less abnormality. Finally, rainfall variation assessment depicts that the rainfall conditions in Salem districthas normal and fluctuation depends on time and space.

\section{REFERENCES}

[1] Ahmadi, A., Moridi, A., Lafdani, E. K., \& Kianpisheh, G. (2014). "Assessment of climate change impacts on rainfall using large scale climate variables and downscaling models-A case study". Journal Earth Syst. Sci.123.

[2] Gurugnanam, B., Suresh, M., Vinoth, M., and Kumaravel. S (2010). "High/low rainfall domain mapping using GIS at Salem district, Tamil Nadu, India”. Indian Journal of Science and Technology. v.3 (5), pp.542-545.

[3] Hengxing, L. A. N., Faquan, W. U., Chenghu, Z., \& Lingjuan, W. (2003). "Spatial hazard analysis and prediction on rainfall-induced landslide using GIS". Chinese Science Bulletin. Vol.48:703-708.

[4] Jegankumar, R., Nagarathinam, S. R., \& Kannadasan, K. (2012)." Spatial distribution of rainfall in Salem and Namakkal districts". International Journal of Geomatics and Geosciences. Vol.2 (4).

[5] Mari R.Tye and Daniel Cooley (2015). "A spatial model of examine rainfall extremes in Colorado's Front Range". Journal of Hydrology.530:15-23

[6] Mahalingam et.al. (2014)." Rainfall variability in space and time, a case of Mysore district, Karnataka, India”. Current Trends in Technology and Science. 3(3).

[7] Ochoa-rodriguez, S., Wang, L., Gires, A., Daniel, R., Reinoso-rondinel, R., Bruni, G., ... Veldhuis, M. (2015). "Impact of spatial and temporal resolution of rainfall inputs on urban hydrodynamic modelling outputs: A multi-catchment investigation". Journal of Hydrology. 
[8] Okan Fistikoglu and Nilgun B. Harmancioglu (2002). "Integration of GIS with USLE in Assessment of Soil erosion". Water resources management16:447-467.

[9] Priyadharshini and Arucham (2015). "Rainfall Trends and Pattern of Sweta Nadhi basin, Salem District, Tamil Nadu, India using GIS”. International journal for Innovative Research in Science and Technology.1 (8).

[10] Rico-ramirez, M. A., Liguori, S., \& Schellart, A. N. A. (2015). "Quantifying radar-rainfall uncertainties in urban drainage flow modelling". Journal of Hydrology.528: 17-28.

[11]Renji Remesan and Ian P.Holman (2015). "Effect of baseline meteorological data selection on hydrological modelling of climate change scenarios". Journal of Hydrology. 528:631-642.

[12] Suk, W., Steven, H., \& Marshall, J. B. J. (2011). "Assessment of satellite-based rainfall estimates in urban areas in different geographic and climatic regions". Natural Hazards 56:733-747.

[13] Shi-biao, B. A. I., Chen, C., Jian, W., Thiebes, B., \& Zhi-gang, Z. (2013). "Regional scale rainfall-and Earthquake triggered landslide susceptibility assessment in Wudu Country, China". 10(5):743-753.

[14] Sang-soo Jeon (2014). "Damage pattern recognition of spatially distributed slope damages and rainfall using optimal GIS mesh dimensions". Journal of Mt.Sci.11 (2): 336-344.

[15] Theodosios Kritikos and Tim Davies (2014). "Assessment of rainfall-generated shallow landslide/debris-flow susceptibility and runout using a GIS-based approach: application to western southern Alps of New Zealand". Landslides.

[16] Thilagavathi, N., Subramani, T., Suresh, M., \& Ganapathy, C. (2014). "Rainfall variation and groundwater fluctuation in Salem chalk hills area, Tamil Nadu, India”. International Journal of Application or Innovation in Engineering and Management. Vol.3 (1).

[17] Tharanitharan Venkatesan and Srinivasan Krishnomoorthy (2014). "A comparative assessment on ground water quality of rural and city locations of Salem district, Tamil Nadu, India". Journal of Chemical and Pharmaceutical Research, 6(2).

[18] Williams, C. J. R., Kniveton, D. R., \& Layberry, R. (2010). "Assessment of a climate model to reproduce rainfall variability and extremes over Southern Africa”. Theor Appl Climatol 99:9-27.
[19] Wei-Chiang Hong and Ping-Feng Pai (2007)." Potential assessment of the support vector regression technique in rainfall forecasting". Water Resource Management.21:495-513.

[20]Zaheer ahmad babar and Xie-fei zhi (2015). "Precipitation assessment of Indian summer monsoon based on CMIP5 climate simulations". Arabian Journal of Geosciences.8:4379-4392.

[21]Zekai sen and Zeyad habib (2000)."Spatial precipitation assessment with elevation by using point cumulative semivariogram technique". Water resources management 14:311-325. 


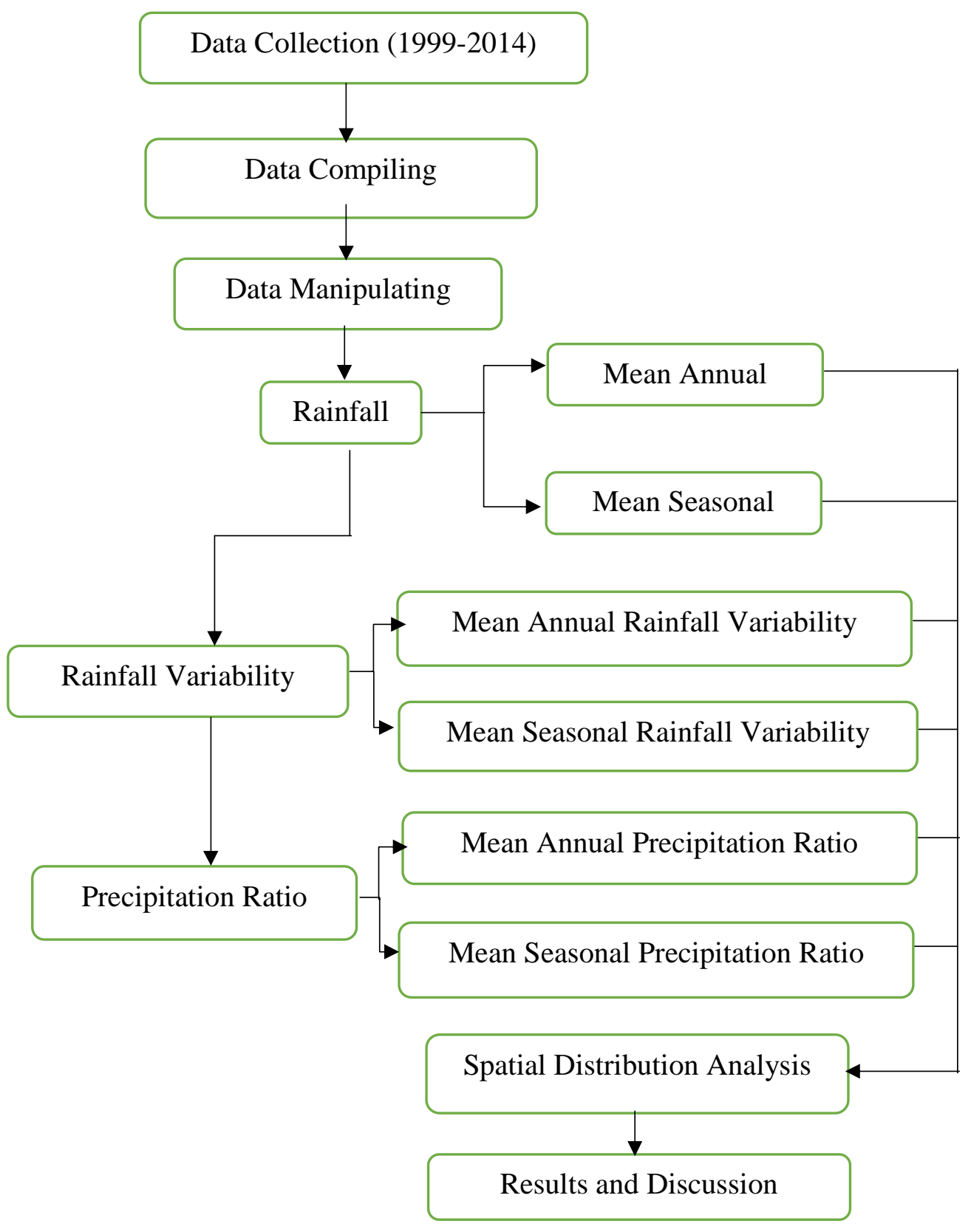

Fig.1:Flow chart-Methodology 


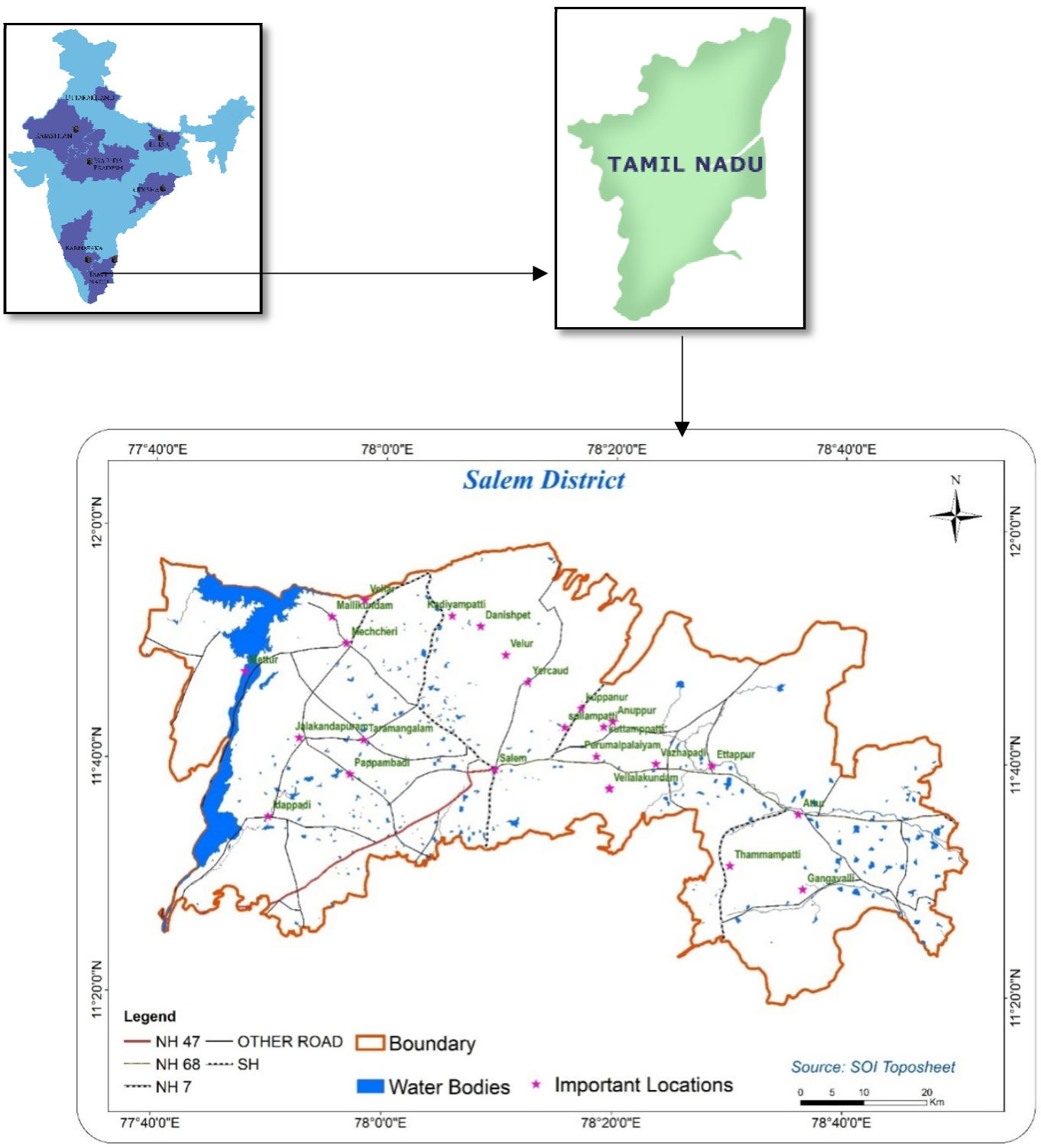

Fig.2: Location map of the Study Area 


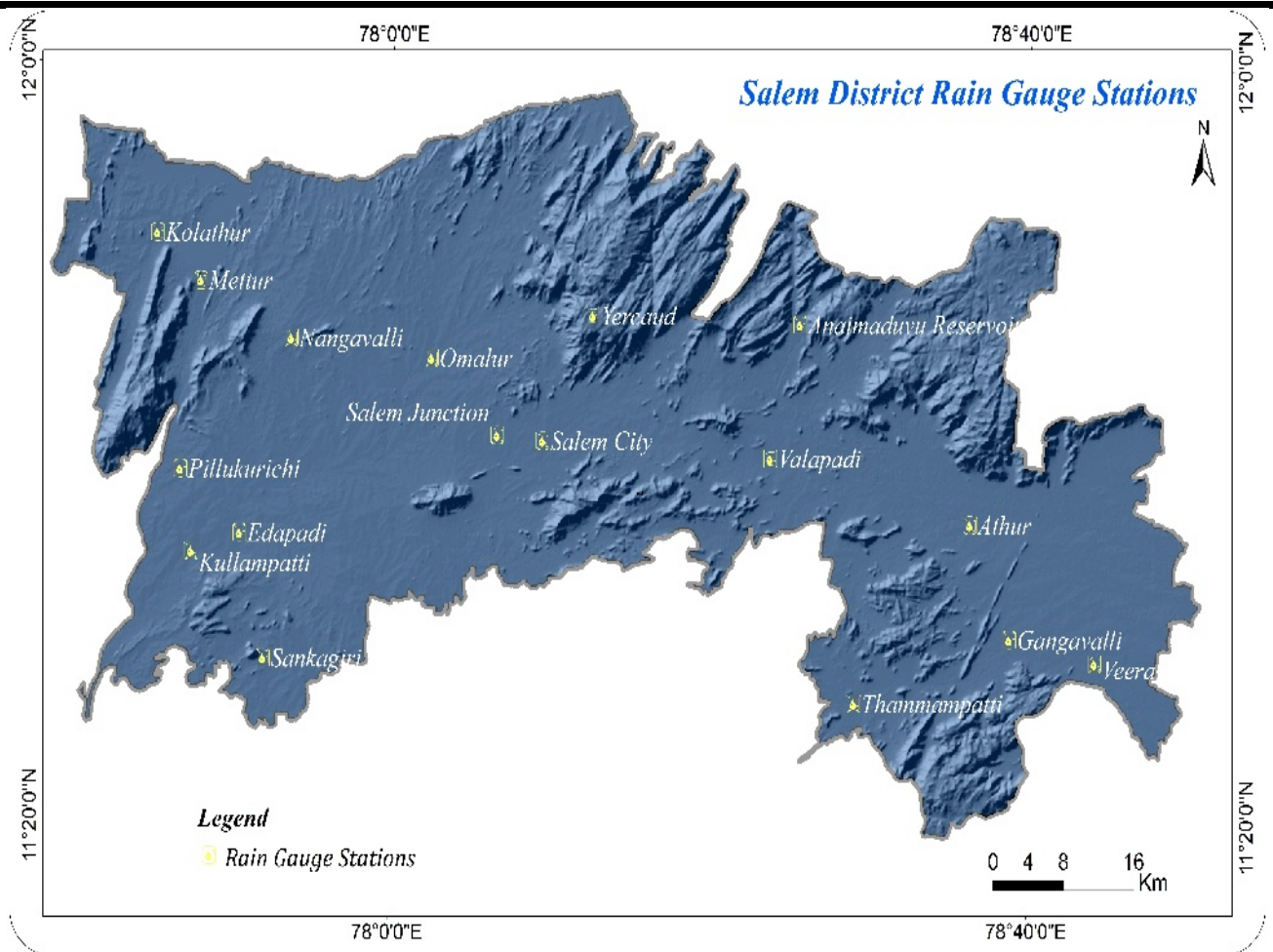

Fig. 3:Rain gauge stations of the study area

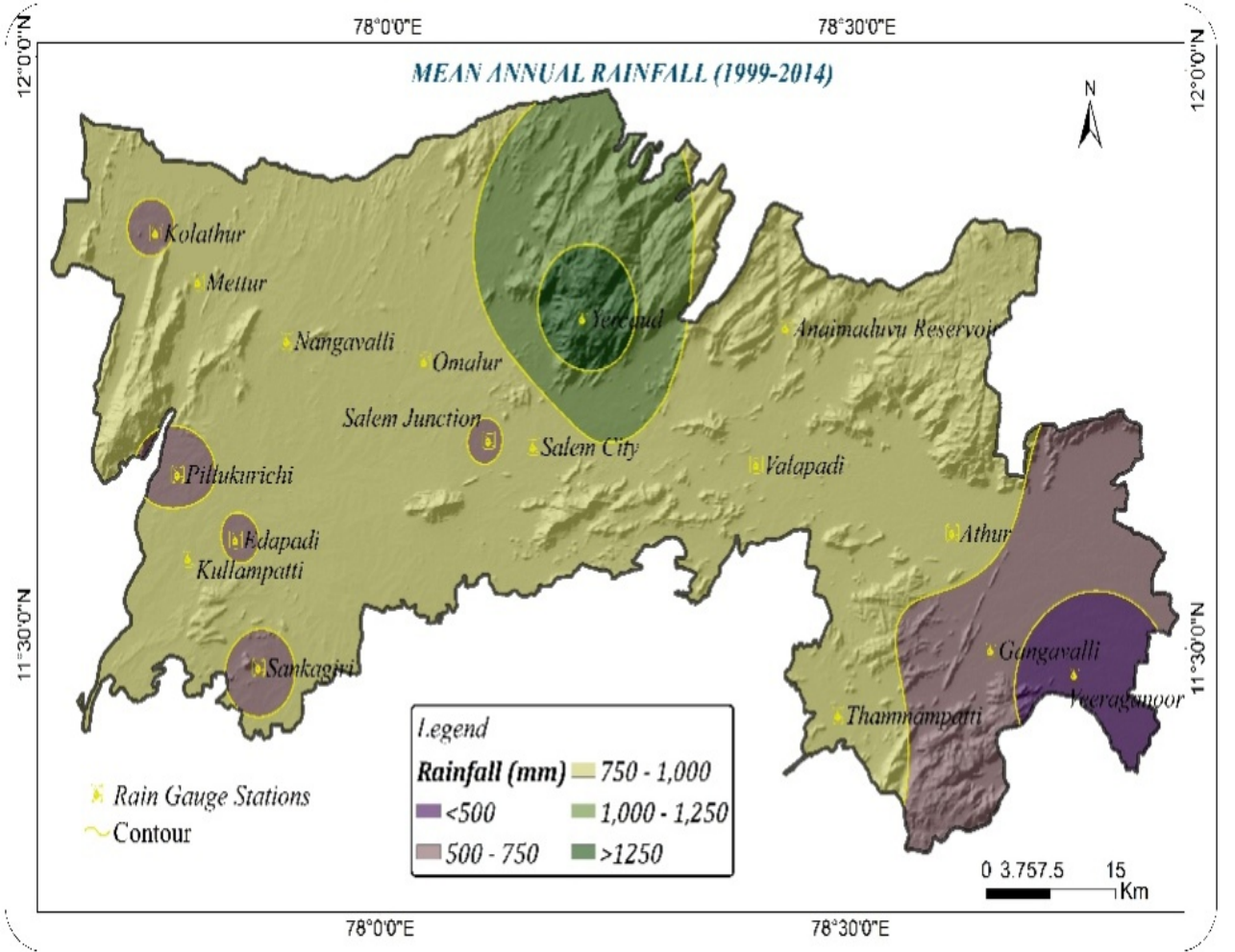

Fig.4:Spatial distribution of mean annual rainfall 


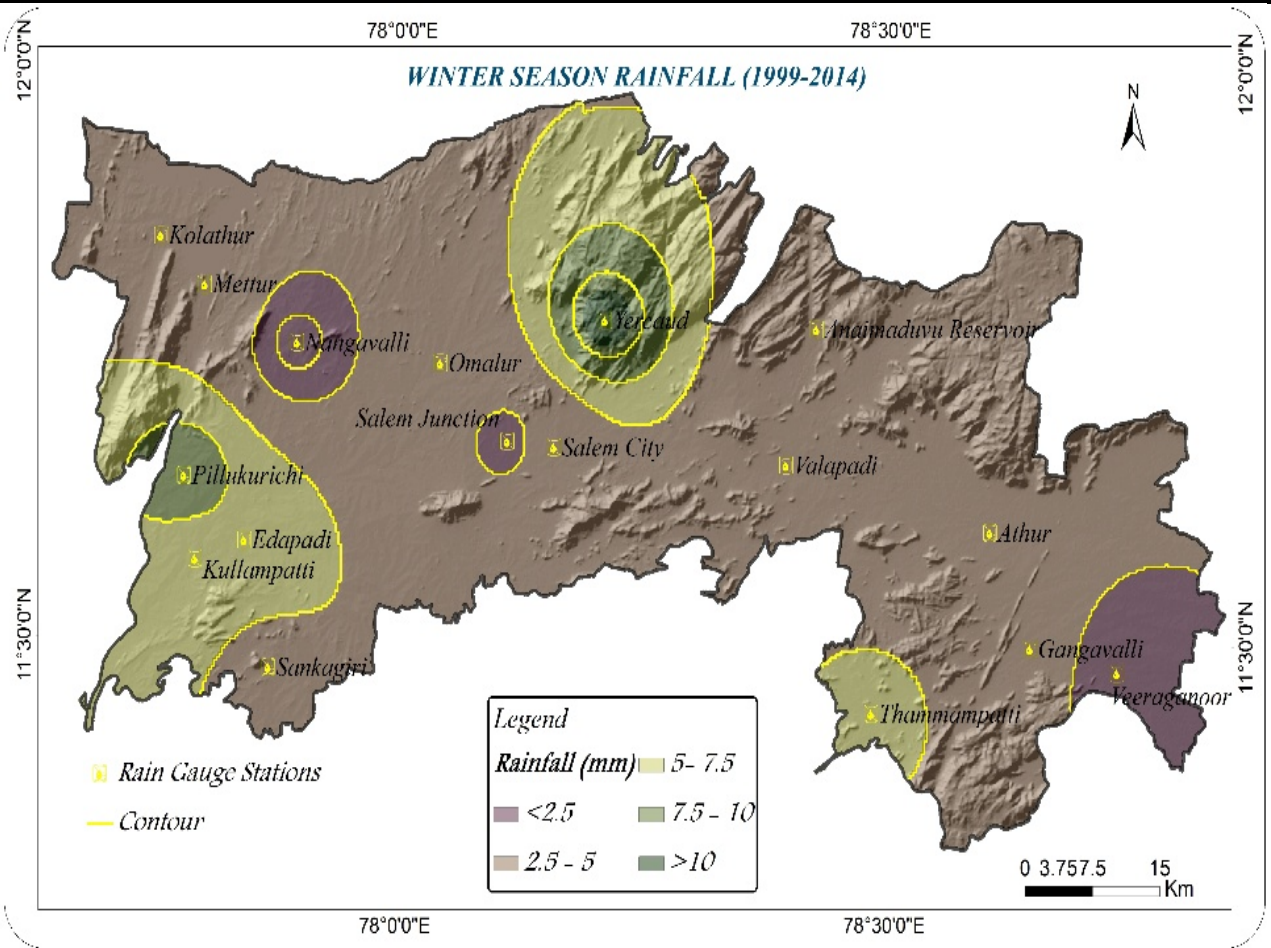

Fig.5:Spatial distribution of winter season rainfall

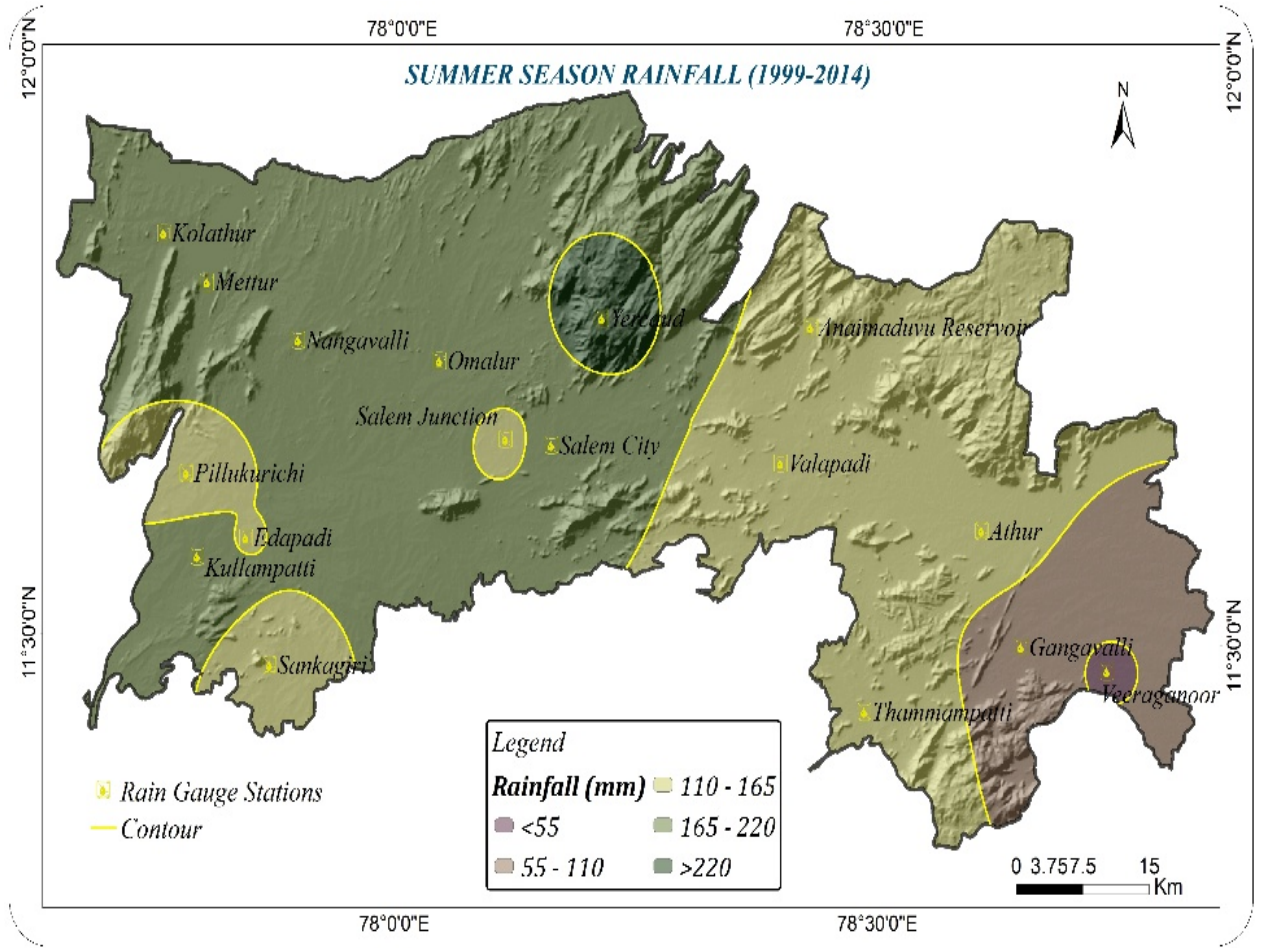

Fig.6:Spatial distribution of summer season rainfall 


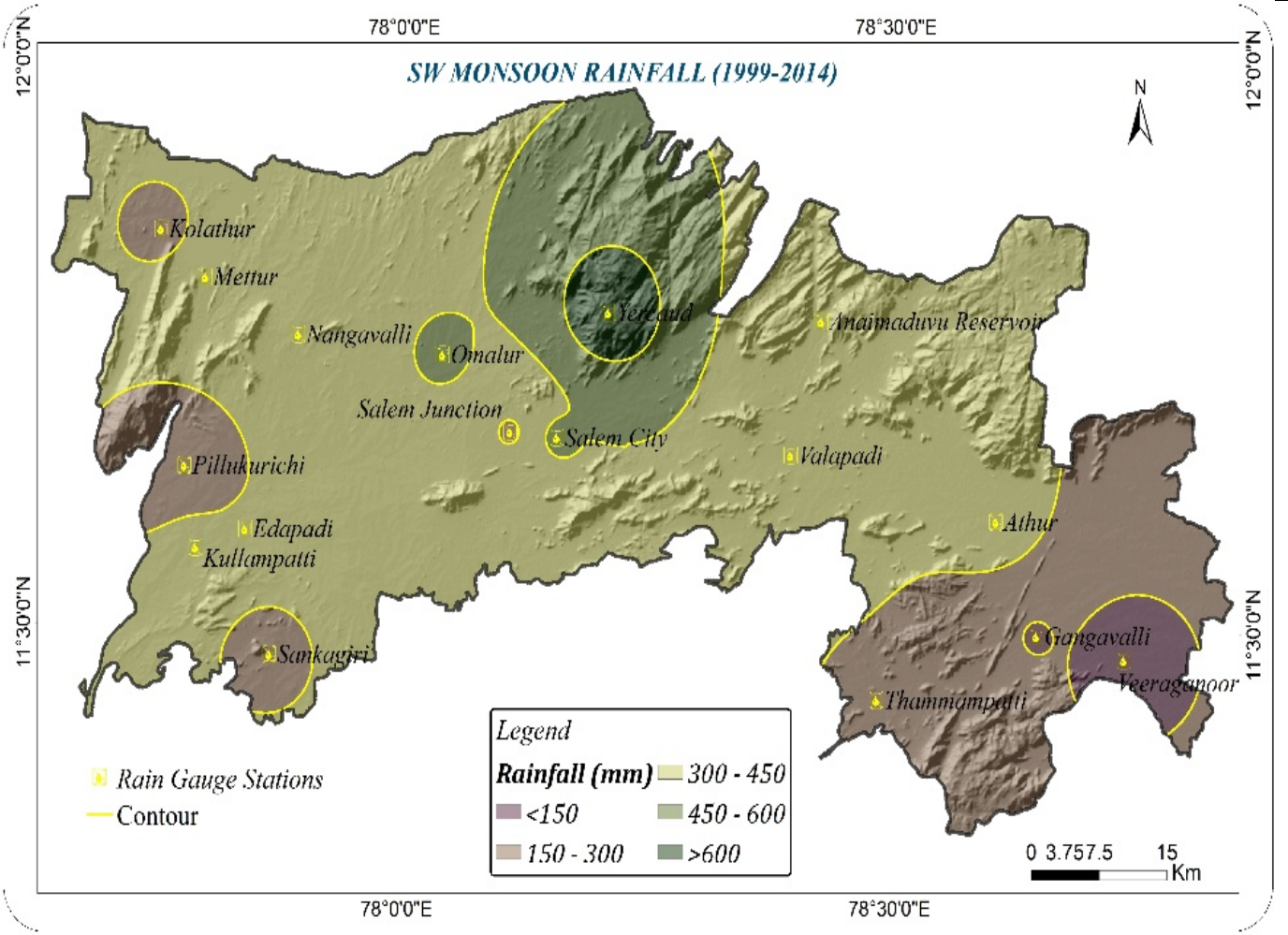

Fig.7:Spatial distribution of SW monsoon rainfall

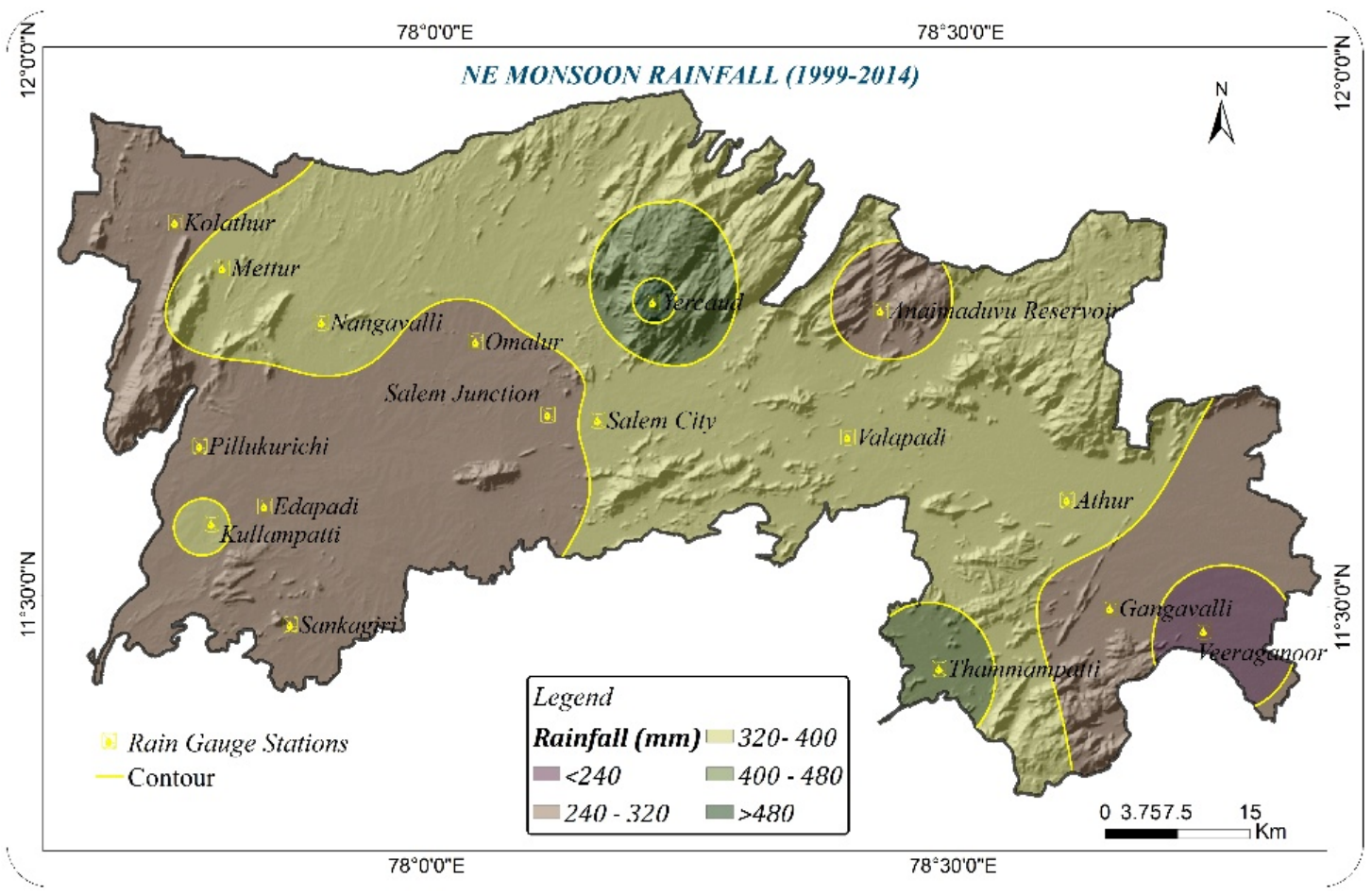

Fig.8:Spatial distribution of NE monsoon rainfall 


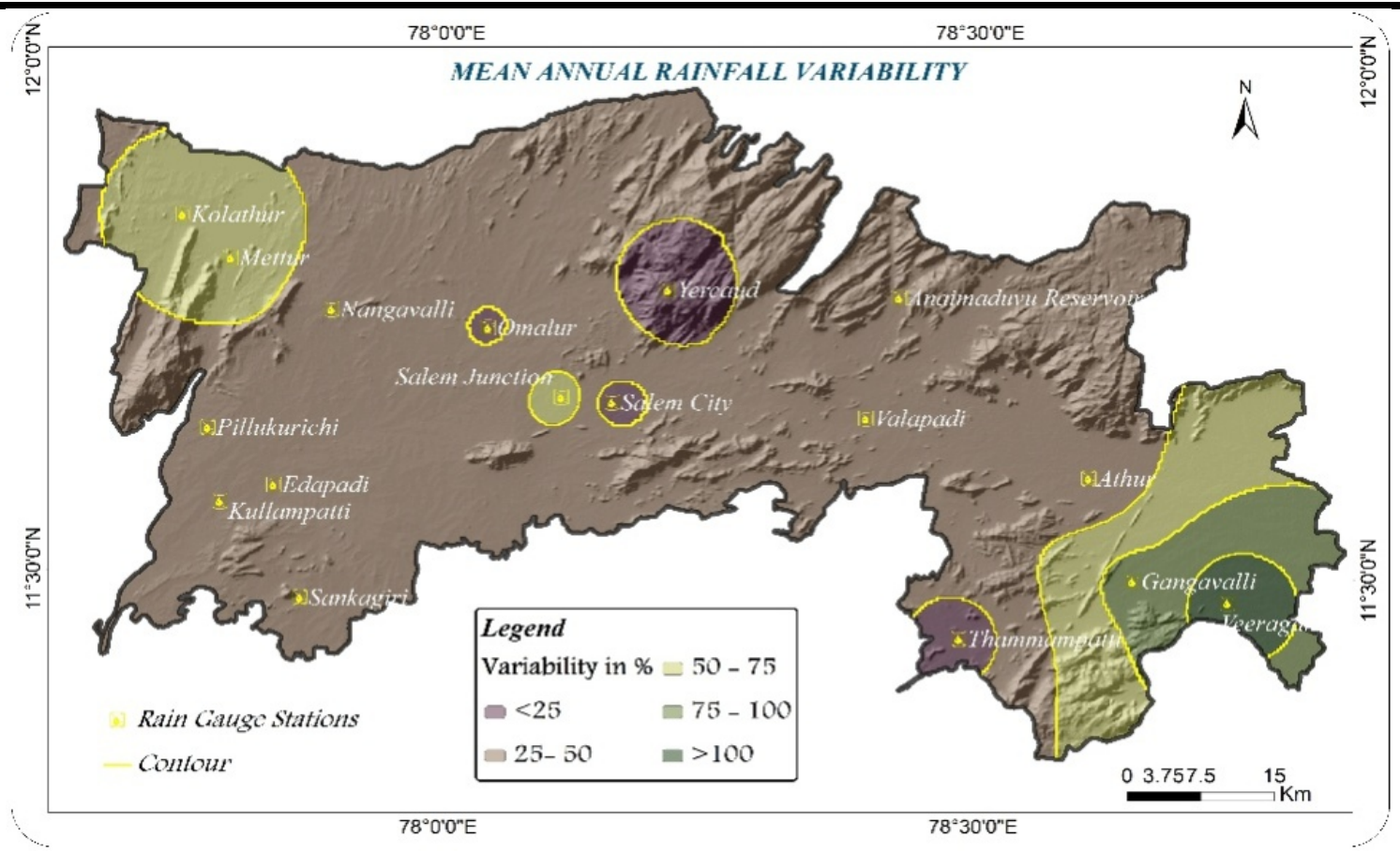

Fig.9: Spatial distribution of mean annual rainfall variability

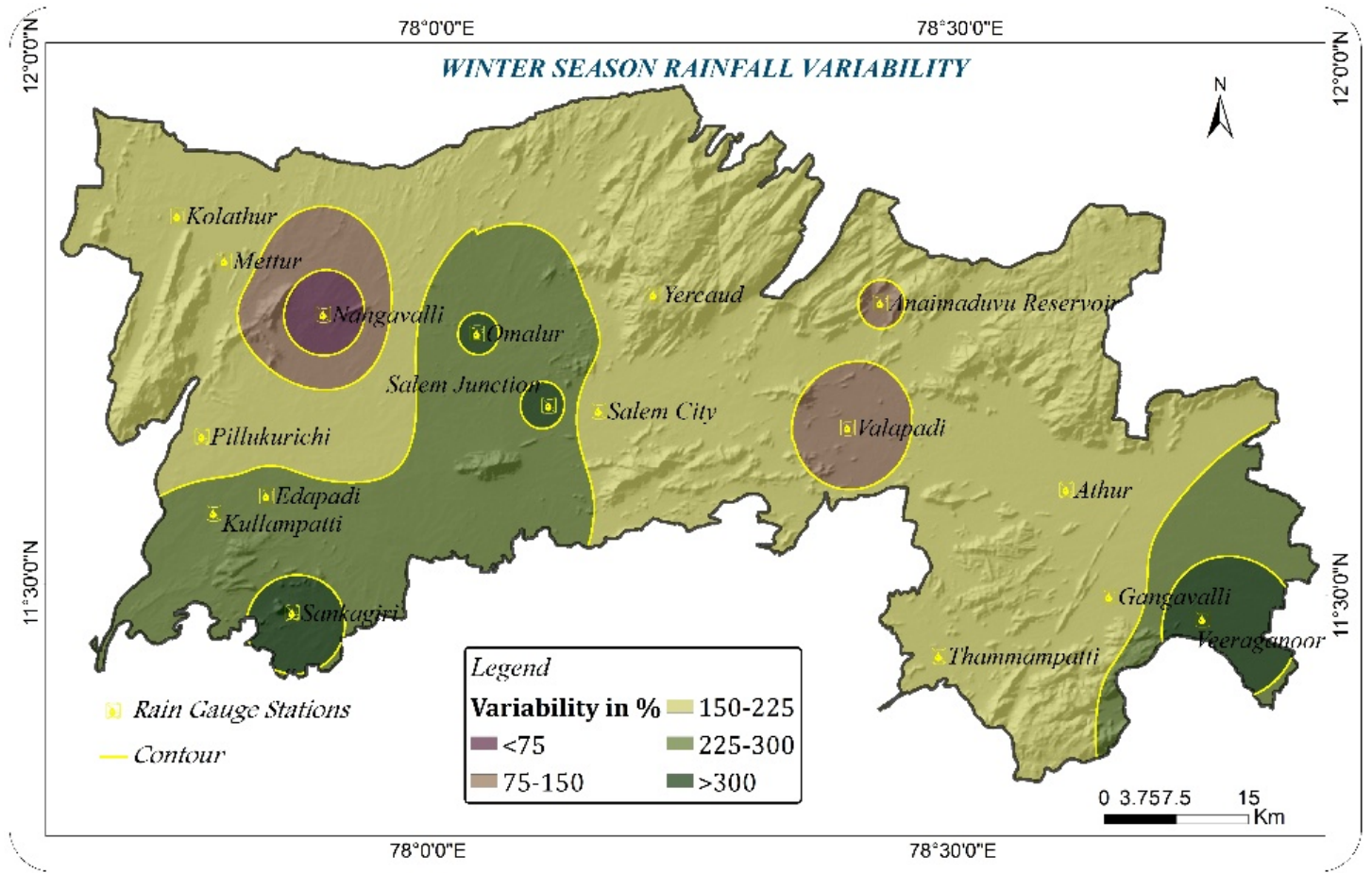

Fig.10:Spatial distribution of winter season rainfall variability 


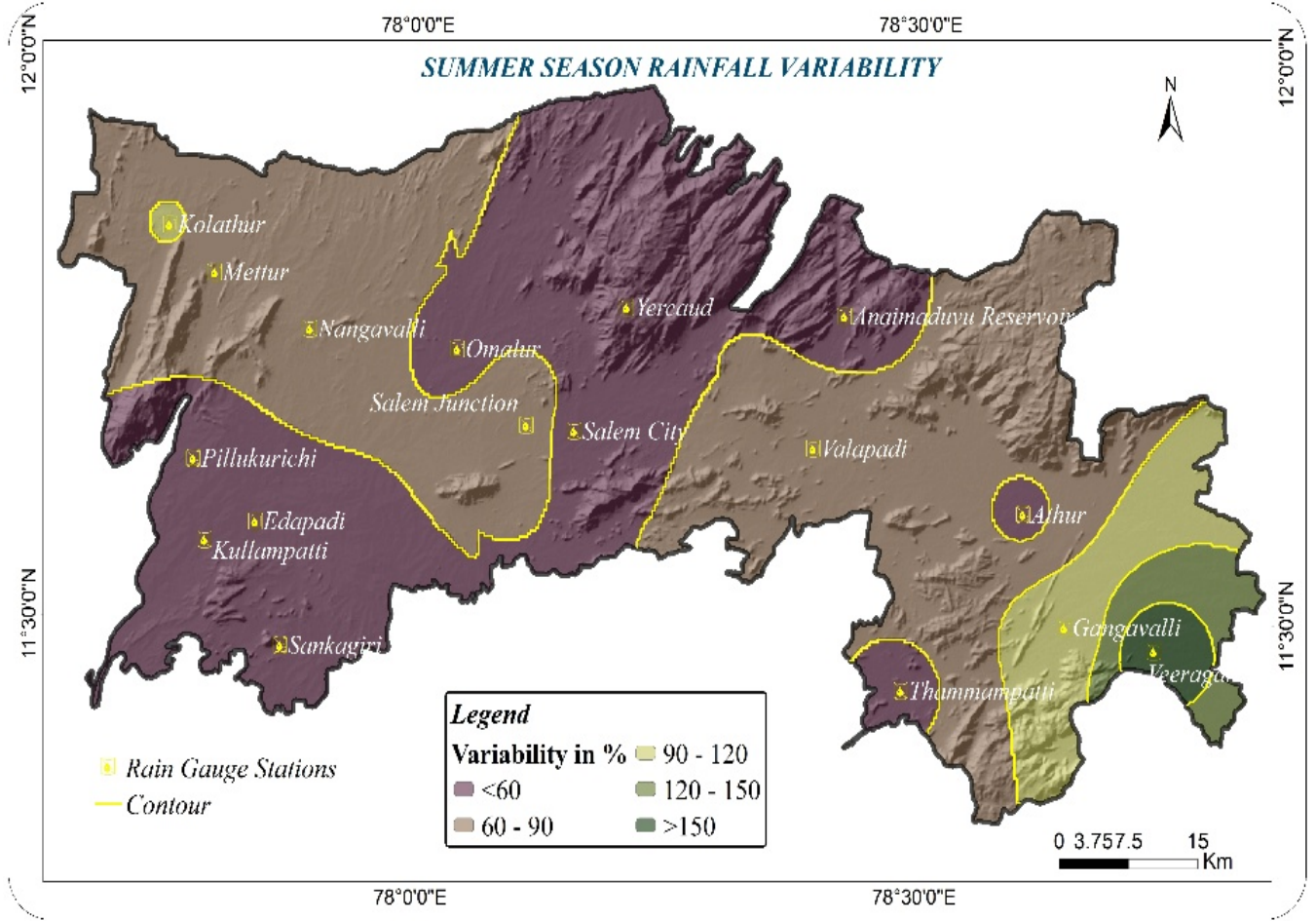

Fig.11:Spatial distribution of summer season rainfall variability

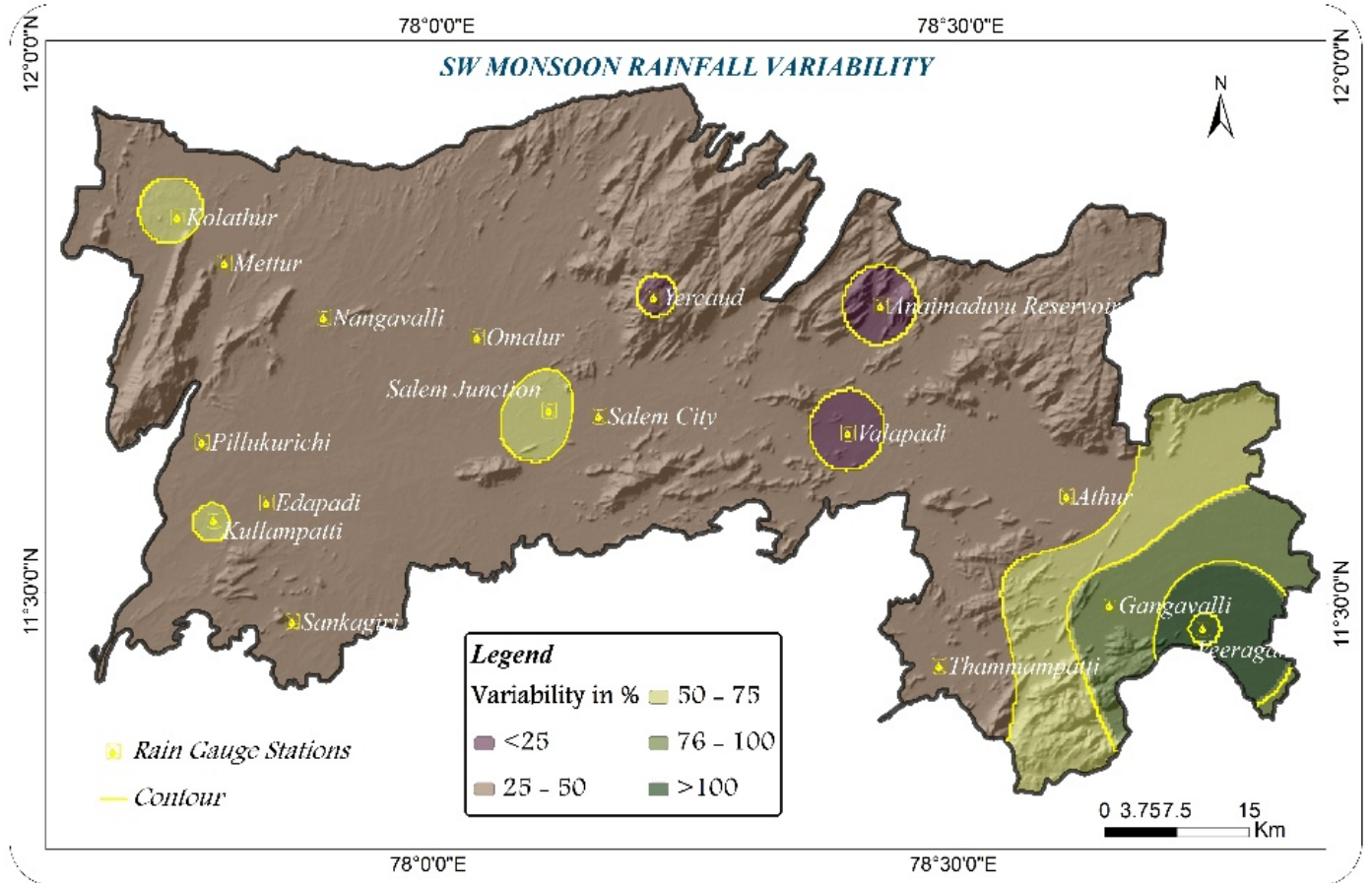

Fig.12:Spatial distribution of SW monsoon rainfall variability 


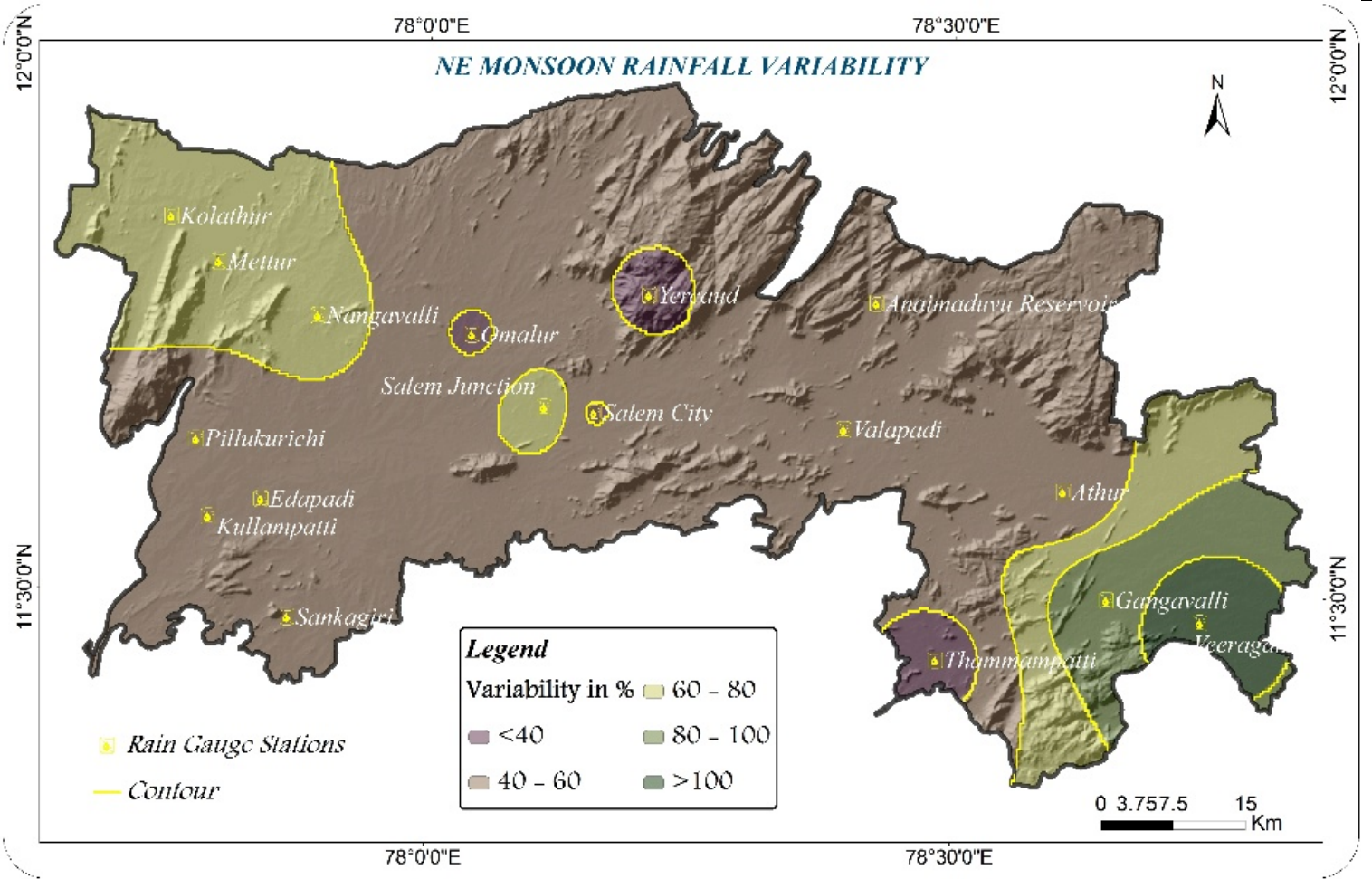

Fig.13:Spatial distribution of NE monsoon rainfall variability

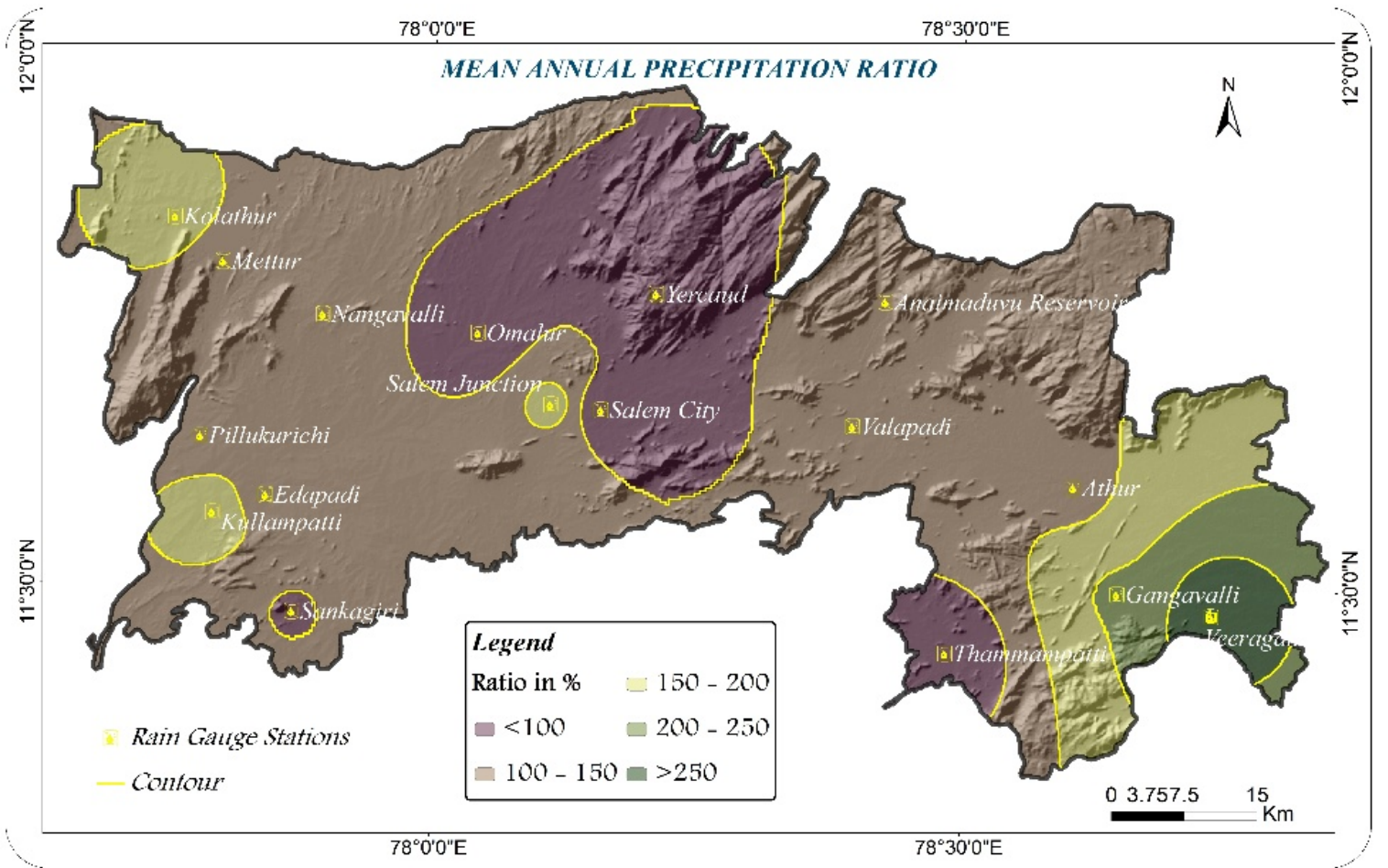

Fig.14:Spatial distribution of mean annual precipitation ratio 


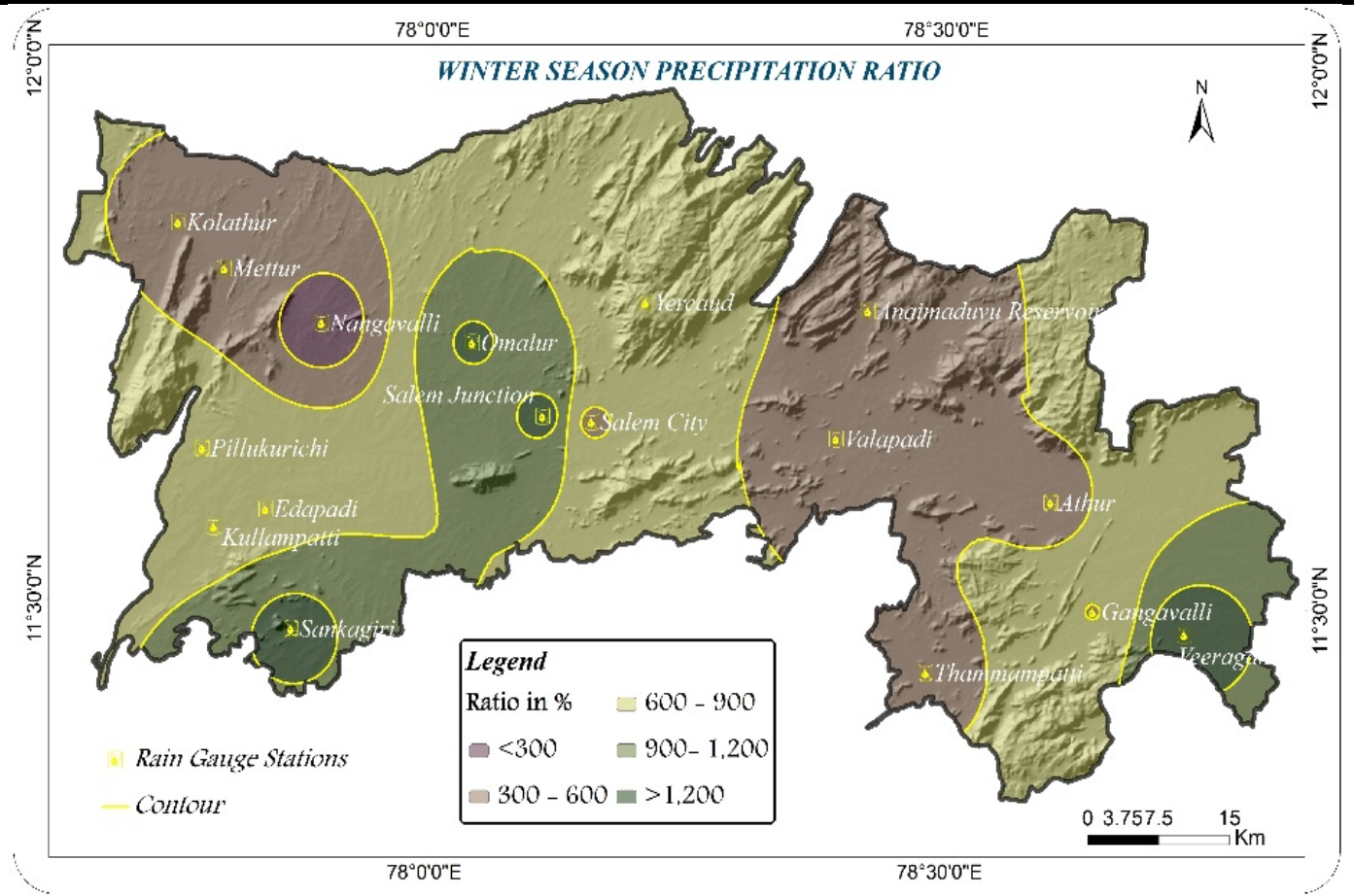

Fig. 15:Spatial distribution of winter season precipitation ratio

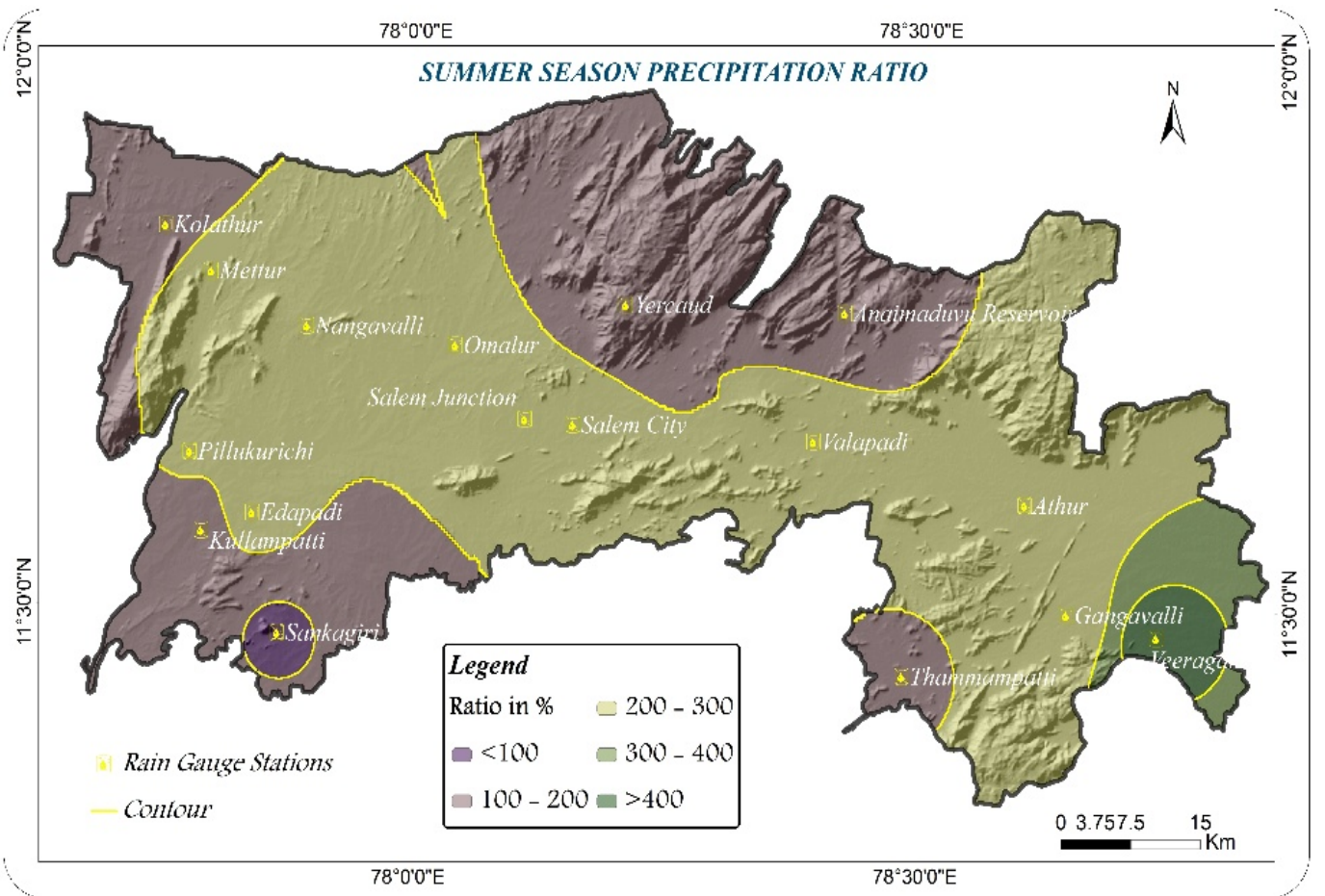

Fig. 16:Spatial distribution of summer season precipitation ratio 


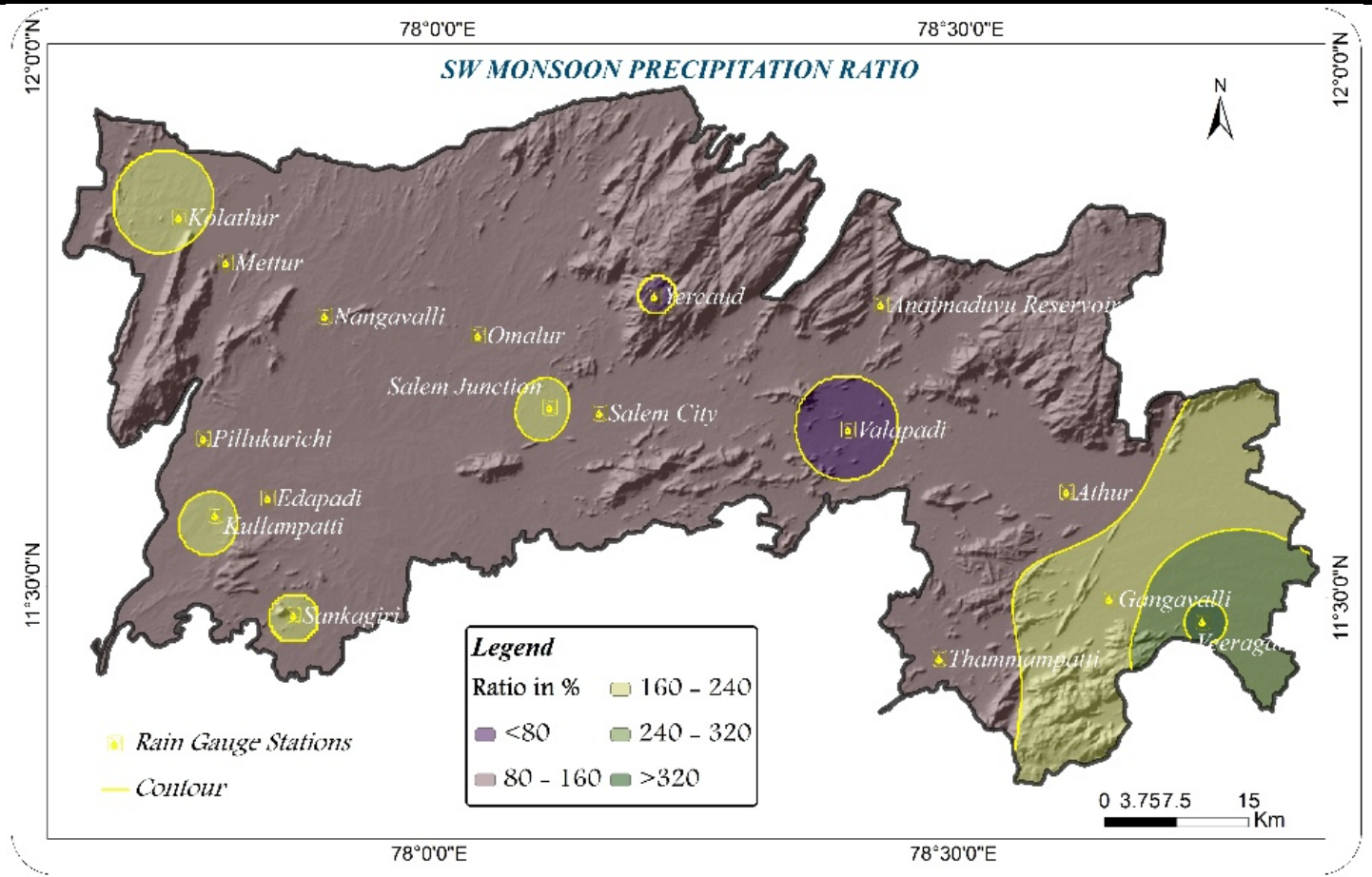

Fig.17:Spatial distribution of $S W$ monsoon precipitation ratio

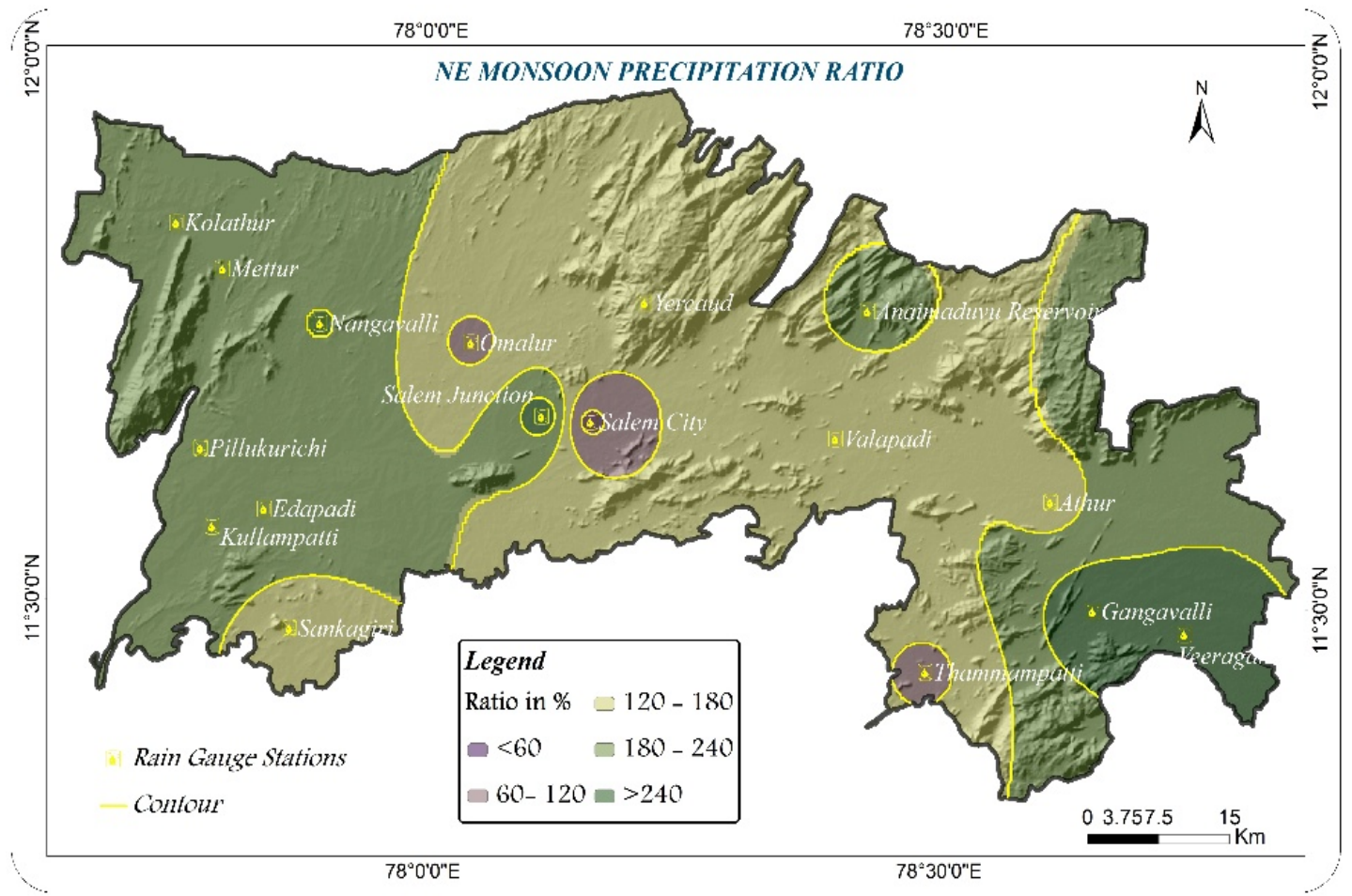

Fig. 18:Spatial distribution of NE monsoon precipitation ratio 
Table.1:Annual and seasonal rainfall of the study area

\begin{tabular}{|c|c|c|c|c|c|}
\hline Station & $\begin{array}{l}\text { Winter } \\
(\mathrm{mm})\end{array}$ & $\begin{array}{l}\text { Summer } \\
(\mathrm{mm})\end{array}$ & $\mathrm{SW}(\mathrm{mm})$ & $\mathrm{NE}(\mathrm{mm})$ & $\begin{array}{c}\text { Mean } \\
\text { Annual } \\
(\mathrm{mm})\end{array}$ \\
\hline Veeraganur & 0.8 & 46.8 & 91.9 & 189.8 & 329.3 \\
\hline yercaud & 12.5 & 264.2 & 718.9 & 496.0 & 1491.5 \\
\hline Thammampatti & 6.5 & 132.3 & 288.2 & 448.6 & 875.6 \\
\hline Valapadi & 2.7 & 119.2 & 358.5 & 355.3 & 835.8 \\
\hline Omalur & 4.4 & 179.8 & 472.4 & 316.8 & 973.3 \\
\hline Pillukurichi & 10.1 & 142.5 & 240.4 & 309.2 & 702.2 \\
\hline Salem & 4.6 & 173.9 & 464.8 & 346.8 & 990.1 \\
\hline Athur & 3.9 & 129.6 & 359.4 & 392.0 & 884.9 \\
\hline Gangavalli & 4.9 & 97.4 & 144.6 & 254.9 & 501.8 \\
\hline Salem Rly & 1.7 & 157.1 & 288.6 & 244.2 & 691.6 \\
\hline Edapadi & 8.5 & 164.1 & 302.1 & 259.8 & 734.4 \\
\hline Kolathur & 3.9 & 175.2 & 286.1 & 257.9 & 723.1 \\
\hline Anaimaduvu-RES. & 3.3 & 160.4 & 350.5 & 300.4 & 814.6 \\
\hline Kullampatti & 7.0 & 183.5 & 318.4 & 334.3 & 843.1 \\
\hline Mettur & 5.8 & 203.9 & 333.1 & 366.9 & 909.7 \\
\hline Nangavalli & 0.0 & 174.7 & 345.2 & 327.0 & 846.9 \\
\hline Sankagiri & 4.9 & 155.9 & 287.7 & 282.6 & 731.2 \\
\hline Average & 5.0 & 156.5 & 332.4 & 322.5 & 816.4 \\
\hline Percentage & 1 & 19 & 41 & 39 & \\
\hline
\end{tabular}


Table.2: Results of rainfall variability

\begin{tabular}{|c|c|c|c|c|c|}
\hline Station & Winter $\%$ & Summer \% & SW\% & $\mathrm{NE} \%$ & $\begin{array}{l}\text { Mean } \\
\text { annual }\end{array}$ \\
\hline Veeraganur & 374.2 & 174.3 & 128.4 & 120.4 & 119.0 \\
\hline yercaud & 207.1 & 47.8 & 25.1 & 36.6 & 19.4 \\
\hline Thammampatti & 160.1 & 52.6 & 32.3 & 32.4 & 19.2 \\
\hline Valapadi & 125.6 & 81.6 & 22.7 & 44.0 & 30.3 \\
\hline Omalur & 310.7 & 58.4 & 26.7 & 37.6 & 23.7 \\
\hline Pillukurichi & 198.9 & 52.9 & 29.8 & 57.0 & 31.8 \\
\hline Salem & 163.2 & 50.9 & 26.0 & 37.8 & 19.9 \\
\hline Athur & 164.2 & 55.3 & 31.8 & 42.3 & 32.7 \\
\hline Gangavalli & 180.6 & 105.7 & 84.1 & 100.0 & 79.7 \\
\hline Salem Rly & 330.2 & 74.1 & 70.1 & 75.1 & 60.6 \\
\hline Edapadi & 230.1 & 60.9 & 30.8 & 54.1 & 34.9 \\
\hline Kolathur & 197.9 & 93.8 & 56.3 & 77.0 & 51.7 \\
\hline Anaimavu-RES & 148.3 & 49.1 & 24.5 & 54.6 & 31.8 \\
\hline Kullampatti & 242.5 & 45.1 & 53.6 & 54.9 & 39.2 \\
\hline Mettur & 155.2 & 60.8 & 28.4 & 63.4 & 71.3 \\
\hline Nangavalli & 0.0 & 71.0 & 41.8 & 68.2 & 40.5 \\
\hline Sankagiri & 339.6 & 49.4 & 47.8 & 43.4 & 28.8 \\
\hline Average & 207.6 & 69.6 & 44.7 & 58.8 & 42.6 \\
\hline
\end{tabular}


Table.3: Results of precipitation ratio

\begin{tabular}{|c|c|c|c|c|c|}
\hline Station & Winter \% & Summer\% & SW\% & $\mathrm{NE} \%$ & $\begin{array}{c}\text { Mean } \\
\text { annual\% }\end{array}$ \\
\hline Veeraganur & 1437.5 & 486.4 & 330.7 & 269.9 & 301.4 \\
\hline yercaud & 783.2 & 143.8 & 78.4 & 123.0 & 71.9 \\
\hline Thammampatti & 521.1 & 180.5 & 118.6 & 112.3 & 54.9 \\
\hline Valapadi & 336.4 & 246.6 & 62.9 & 134.7 & 102.7 \\
\hline Omalur & 1250.0 & 205.5 & 112.1 & 107.8 & 53.7 \\
\hline Pillukurichi & 765.9 & 207.0 & 102.0 & 224.3 & 129.7 \\
\hline Salem & 535.6 & 232.1 & 101.2 & 48.1 & 70.8 \\
\hline Athur & 548.7 & 209.5 & 99.2 & 169.9 & 139.0 \\
\hline Gangavalli & 595.9 & 206.1 & 232.0 & 279.0 & 204.2 \\
\hline Salem Rly & 1325.3 & 226.5 & 188.3 & 268.6 & 170.7 \\
\hline Edapadi & 831.4 & 246.7 & 110.6 & 223.4 & 131.9 \\
\hline Kolathur & 576.5 & 164.8 & 195.8 & 235.7 & 183.4 \\
\hline Anaimavu-RES & 484.8 & 142.1 & 86.4 & 191.1 & 110.5 \\
\hline Kullampatti & 828.6 & 159.2 & 183.3 & 240.1 & 181.3 \\
\hline Mettur & 539.1 & 225.7 & 83.6 & 210.8 & 114.2 \\
\hline Nangavalli & 0.0 & 227.5 & 100.5 & 243.1 & 124.3 \\
\hline Sankagiri & 1359.0 & 70.9 & 164.0 & 139.6 & 96.5 \\
\hline Mean & 748.2 & 210.7 & 138.2 & 189.5 & 131.8 \\
\hline
\end{tabular}

